SOUTH AFRICA 2010:

ECONOMIC SCOPE AND LIMITS

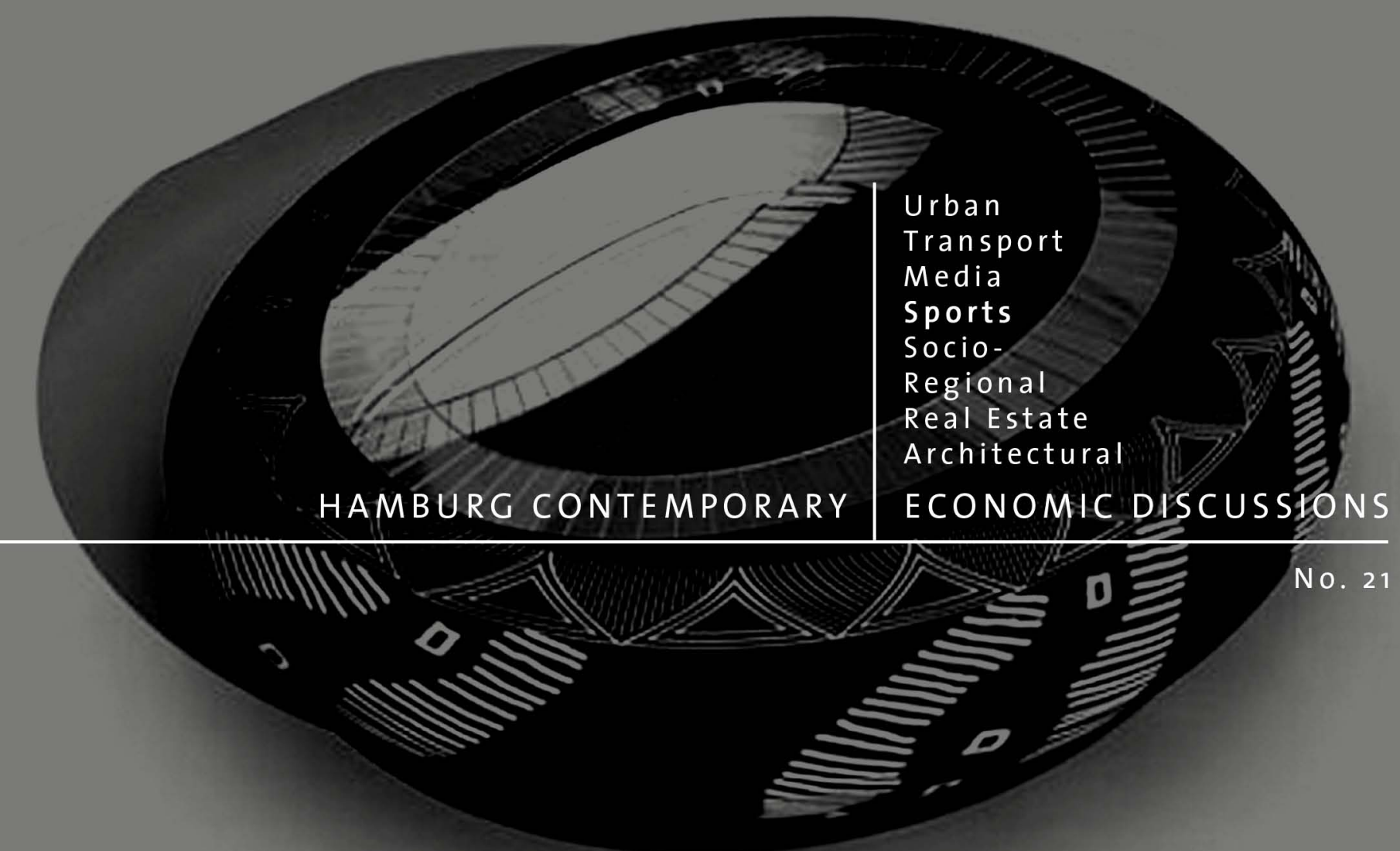


Hamburg Contemporary Economic Discussions

University of Hamburg

Faculty Economics and Social Science

Chair for Economic Policy

Von-Melle-Park 5

D-20146 Hamburg | Germany

Tel $+494042838-4622$

$\mathrm{Fax}+494042838-6251$

http://www.uni-hamburg.de/economicpolicy/

Editor: Wolfgang Maennig

Swantje Allmers

University of Hamburg

Faculty Economics and Social Science

Von-Melle-Park 5

D-20146 Hamburg | Germany

Tel $+494042838-4679$

Fax +494042838 - 6251

hced@econ.uni-hamburg.de

Wolfgang Maennig

University of Hamburg

Faculty Economics and Social Science

Chair for Economic Policy

Von-Melle-Park 5

D-20146 Hamburg | Germany

Tel $+494042838-4622$

$\mathrm{Fax}+494042838-6251$

maennig@econ.uni-hamburg.de

ISSN 1865 - 2441 (Print)

ISSN 1865 - 7133 (Online)

ISBN 978 - 3 - $940369-56$ - 7 (Print)

ISBN 978 - 3- 940369 - 57 - 4 (Online) 


\title{
South Africa 2010: Economic Scope and Limits
}

\begin{abstract}
This contribution provides an ex post analysis of the economic impacts of the two most recent single-country World Cups (WCs), Germany 2006 and France 1998. Based on macroeconomic indicators, the experiences of these WCs appear to be in line with existing empirical research on large sporting events and sports stadiums, which have rarely identified significant net economic benefits. Of more significance are the novelty effects of the stadiums, and "intangible effects" such as the image effect for the host nations and the feel-good effect for the population.

The experiences of former WCs provide a context for analysing the scope and limits for South Africa 2010. Like previous host countries, South Africa might have to cope with difficulties such as the underuse of most WC-stadiums in the aftermath of the tournament. On the other hand, this paper examines a handful of arguments why South Africa might realise larger economic benefits than former hosts of WCs, such as the absence of the northern-style 'couch potato effect' and the absence of negative crowding-out effects on regular tourism. Furthermore, the relative scarcity of sport arenas in South Africa might induce a larger positive effect than in countries with ample provision of sports facilities. In addition, against the backdrop of continuous declines in South African poverty since 2001, the novelty effect of new stadiums might be of special importance. Finally, the innovative South African ambitions to use stadiums with 'signature architecture' as a tool for urban development or to generate external effects for the regional economy are different from former WCs.
\end{abstract}

Keywords: Regional Economics, Sports Economics, World Cup, Stadium Impact, Feelgood Factor JEL classification: L83, R53, R58

Version: January 2008

\section{Introduction}

Hosting a large international sporting event promises not just the excitement of the event and media exposure for the host nation, but also creates the expectation of a positive return on the considerable investment associated with hosting this type of event. This is also true for one of the largest of these events, the FIFA (Fédération Internationale de Football Association) World Cup (WC).

Previous studies of former WCs and other large sporting events have shown only limited positive effects on local economies; this paper examines the most recent single-country WC experiences in Germany 2006 and France 1998 and offers comparisons and contrasts with the plans for the 2010 South African WC. 


\section{Assessing the Economic Impact of World Cup 1998 and 2006}

\subsection{World Cup Effects on Macroeconomic Data}

It is often heard that the economic benefits from hosting a WC stem from additional receipts from tourism, increased turnover in retail business, and positive effects on employment. Although it cannot be denied that individual enterprises and sectors may profit from a WC held in their own country, nation-wide analyses may indicate otherwise, because meso- and macroeconomic data aggregate possible increases in profits and incomes of individuals with the concurrent losses of others.

\section{Income from International Tourism}

The tourism sector is usually expected to be amongst the main beneficiaries of an event like the WC. For France 1998, some 500,000 foreign WC-tourists were expected (SZYMANSKI, 2002). A study for Germany 2006 projected roughly 340,000 foreign tourists, spending between US\$0.62 and 1.1 billion (KURSCHEIDT \& RAHMANN, 1999). The estimate of the German Hotel and Catering Association was even more optimistic, calculating up to 3.3 million foreign tourists (UNTERREINER, 2006). An updated estimate for South Africa by Grant Thornton assumes 300,000 overseas visitors, spending US\$1.36 billion (ZAR 9.3 billion) during WC 2010 (N.N., 2008a).

As correctly implied by the cited studies, analyses of sporting events should evaluate expenditures of non-residents as a driving force to the economy of the host nation. For the residents of the host nation, it can be assumed that their potentially increased expenditures during the sporting event is counterbalanced by reductions in their consumption elsewhere, and that the savings rate overall remains constant, at least in the medium term (MAENNIG, 1998). For this reason, domestic WC-tourism is not regarded in the first stages of analysing the numbers of overnight stays. In a second stage, where the service balance sheet will be examined, domestic travel (abroad) behaviour becomes relevant. 


\section{Overnight Stays}

The broken line in Figure 1 illustrates the amount of overnight stays of foreigners in Germany from 2000 to 2007. On the basis of the raw data, the figures of June 2006 exceed the figures of June 2005 by about 1 million overnight stays (+3.5\%), and by some 159 thousand in July 2006 (+0.5\%). However, the number of overnight stays in Germany also grew an average 3.5\% from 1996 to 2005 pre-WC 2006. With regard to the trend observed for Germany as a whole, the corresponding seasonally adjusted values (Figure 1, continuous line; X12 method, US Census Bureau) do not show any significant increase that can be attributed to the WC 2006. ${ }^{1}$

Furthermore, Figure 2, which shows a comparison of seasonally adjusted overnight stays in Germany in the years 2004 to 2006, illustrates a possible crowdingout effect that has to be balanced against increases during June and July 2006: the WC months were immediately preceded and followed by lower numbers in the months of May and August compared to the previous years. It is conceivable that tourists who would otherwise have travelled to Germany during May and/or August 2006 transferred their stay in a utility-maximizing way to the WC months ('time switching').

France 1998 even experienced a decline in the number of foreigner overnight stays at the time of the WC, which - using raw data - were approximately some 142 thousand (or 1.2\%) lower in June 1998 compared with June 1997. In July 1998, the decrease amounted to 48.5 thousand (0.2\%). Due to incomplete data, it was not possible to examine whether this decline, which applied to all accommodation establishments, is attributable to WC 1998. However, regression analyses following the above mentioned pattern could not find any significant WC-effects

1 Regressions for the period $1 / 1993$ to $9 / 2007$ including a constant, a time trend, a AR(1) term for countervailing serial autocorrelation, and dummies for the months May to August 2006 indicated no significant effect of the dummies for the WC months (June and July 2006). See Tables 2 and 3 in appendix for the results of all regressions mentioned in this contribution.

2 The time-switching effect is not significant as well. 
on the overnight stays of foreigners in hotels which, while declining in June and July 1998 , equalled over $40 \%$ of the total number of overnight stays of foreigners (detailed regression results in Table 2).

\section{Effects on the Service Balance Sheet}

To assess the tourism effect of WCs, it is also worthwhile to look at the statistics of the service balance sheet, in which overnight stays are monetarily valued and the income from international tourism (export of services) is contrasted with the tourist expenditures abroad from people of the host nation (import of services). ${ }^{3}$ A potential additional inflow of foreign currency due to the WC might be counterbalanced by increased travels abroad by locals to avoid noise, traffic jams and other turbulences that are caused by the WC ('carnival effect'). ${ }^{4}$ On the other hand, there may also be locals that stay at home to experience the WC instead of travelling abroad, who, in turn, reduce domestic expenditure in other countries.

In the case of Germany, the Deutsche Bundesbank reports additional income from tourism at US\$ 1.7 billion $^{5}$ (or rather 25.9\%) from June to July 2006 in comparison with the same period in the previous year. ${ }^{6}$ This increase is shown in Figure 3, which illustrates the clear rise in income from international tourism, which although starting in May, well before the WC, was at its highest in June 2006. Despite the findings of a gradual positive trend in German receipts from tourism that occurred anyway regardless of the WC, statistical evidence of a positive in-

3 Expenditure for accommodation and travel within the respective countries are included as well as the consumption of the non-residents.

4 For a description of the 'carnival effect' on the occasion of the German WC 2006 cf. MAENNIG (2007).

5 Conversion on the basis of the US\$/€-exchange of 15 January 2008 (1.4838 US\$/€).

6 The Bundesbank detects certain inaccuracies, since, for example, the additional income of local airlines is not included. On the other hand, ticket sales are included, which go to FIFA (DEUTSCHE BUNDESBANK, 2006).

7 Between 1997 and 2005 the average growth in receipts from international tourism amounted to some $5.1 \%$ per year. 
fluence of WC 2006 can be found. ${ }^{8}$ This increase, however, has to be contrasted with the expenditures of German tourists abroad during June and July 2006, which were clearly above the level of the previous year as well. On the basis of raw data, the net effect of the traditionally passive German tourism service balance reduces to an improvement of US\$ 896 million (+18.7\%) in June 2006 (corresponding to $0.03 \%$ of the German GDP in 2006) and US\$ 125 million (+2.0\%) in July 2006 , which is statistically insignificant.

France 1998 registered increased receipts from international tourism of some US\$795 million in the second and US\$825 million in the third quarter compared to the previous year (raw data). ${ }^{9}$ A concurrent increase of the travel expenditures by French tourists in other nations led to a net effect on the French tourism service balance that was only about US\$303 million $(+7.1 \%)$ in the second and US\$277 million (+5.7\%) in the third quarter of 1998. Thus, no significant WC effects can be isolated for the WC $1998 .^{10}$

To sum up, the effects for the tourism sector, which is usually expected to be amongst the main beneficiaries of such mega-events are small, mostly negligible. Mega-events such as the WC may displace regular tourism from abroad and/or lead to the 'carnival effect'. Tourists who are less WC-enthusiastic might postpone a planned trip to the host nation or even cancel it just because of this event. Common motives are the avoidance of noise and traffic jams, the fear of rising prices or concerns regarding security ${ }^{11}$ (analogue to the 'carnival effect' that leads

8 Regressions following the above mentioned pattern indicated a positive, significant WC-effect (for June 2006) on the receipts from international tourism (period 1/1993 to 9/2007).

9 The service balance sheet data for France have only been available as quarterly figures.

${ }^{10}$ Regressions for the period Q1/1994 to Q2/2007 that include dummies for the WC quarters of 1998, dummies for the quarter before and after the tournament, a constant, a time trend variable, and an AR(1)term as explanatory variables, did not indicate any significant WC-effects on the income from international tourism, the expenditure for international tourism and the tourism service balance.

${ }^{11}$ On the central role of fighting crime on the occasion of the WC 2010 see BOB, SWART, \& TURCO (2006). 
to increased trips abroad from locals). In addition, any positive effects in WC months should be checked for a 'time-switching' effect.

\section{Effects on Retail Sales}

The retail industry usually hopes for positive effects from hosting a WC due to the expectation of increased foreign and domestic consumption.

The latter argument is theoretically problematic at the outset. Even if individual enterprises and sectors may profit from a WC, ${ }^{12}$ it has to be assumed that this will be compensated for by reduced demand in other months and/or for other goods, as long as the national savings rate remains constant. Analyses of the consumption expenditure of private households in France and Germany support this view, indicating no significant effects of the WCs in 1998 and 2006 (Table 2 and 3).

Furthermore, examination of the deflated monthly retail sales index does not show any significant impact of WCs, neither for France nor for Germany. ${ }^{13}$ Figure 4 represents the percent change in retail sales figures compared with the same months of the previous year for the German example, and reveals that the WC months of June and July 2006 were actually characterized by decreases in turnover. This negative impact of the WC on retail sales - though statistically not significant - could be referred as the 'couch potato effect': consumers might have been diverted from their normal consumption behaviour by the WC itself, the matches in the stadiums, or the 'Fan-Mile' street markets. Or they might have chosen to entertain themselves at home by watching the live broadcasts of the football and restricting themselves to the consumption of fast food (MAENNIG \& DU PLESSIS, 2007a).

${ }^{12}$ In the case of the WC 2006 businesses as beer breweries (N.N., 2006b), producers of soccer merchandising and tabletop soccer (RITTER, 2006) and transport enterprises as the national railway company Deutsche Bahn (N.N., 2006a) reported positive effects for example.

${ }^{13}$ It has to be considered that these numbers do not include possible increases in sales at filling stations and in the 'Fanfests'. 


\section{Employment Effects}

Citing expected increases in tourism and retail trade, ex ante studies regularly predict growing employment figures as a consequence of major sporting events. The creation of some 350,000 jobs through WC 2002 had been predicted by the Korean Development Institute (FINER, 2002). A survey undertaken by the Deutscher Industrie- und Handelskammertag (German Association of Chambers of Industry and Commerce) projected 60,000 new jobs from WC 2006 (DIHT, 2006). Regarding WC 2010, GRANT THORNTON (2004) assumes that the equivalent of 196,400 annual jobs will be created and sustained through the expenditures of foreign visitors, and that the equivalent of 368,250 annual jobs will be sustained between 2006 and 2010 as a consequence of WC-related construction activities (N.N., 2006b).

During both WCs 1998 and 2006, France and Germany experienced an increase in employment figures at the time of the tournament: The (seasonally adjusted) mean number of employees in Germany rose in June 2006 by 323 thousand employees (equivalent to $0.83 \%$ ) compared to the previous year. The increase in July 2006 amounted to 352 thousand employees (0.91\%). France registered in the second quarter of 1998 a mean employment that was some 425 thousand employees (or $3.11 \%$ ) higher than in the preceding year and the boost in the third quarter was about 420 thousand employees (3.06\%). ${ }^{14}$ Here, too, such developments have to take into account a general employment trend, which had been positive in both nations in the WC years. The mean employment in France 1998 rose by some $1.1 \%$, and in Germany 2006 by about $1.98 \%$ compared to the previous years; throughout 1998 and 2006 respectively, the employment figures exceeded

${ }^{14}$ The numbers of employees in France have only been available as quarterly figures and are seasonally adjusted as well. 
the values of the corresponding months/quarters of the year before. Hence, statistical evidence of significant employment effects is hard to find for both WCs. ${ }^{15}$

Altogether, it must be taken as an interim result that most of the effects on tourism, retail sales and employment that feature in the foreground of discussions about the economics of WCs turn out, at least in the short term, to be substantially smaller than previously supposed. ${ }^{16}$ This sober view regarding short-term economic effects on income and employment is confirmed by further econometric studies of $\mathrm{WCs}^{17}$ as well as by studies that attend to other major sporting events. Whether positive effects from hosting mega-events like the WC can be seen in the medium- or long-term seems unclear as well. ${ }^{18}$

\subsection{World Cup Stadiums, Novelty Effect, and Urban Development}

For Germany 2006 the expenditures on the WC-stadiums (of which four were newly built) reached more than US\$2 billion (FEDDERSEN, MAENNIG, \& BORCHERDING, 2006). ${ }^{19}$ In contrast, France spent less than US\$500 million by re-

15 Regressions performed on the above mentioned samples yielded no significant values for the WC dummies for the period $1 / 1993$ to 9/2007 (Germany) and Q1/1993 to Q3/2007 respectively (France). Moreover, no significant effects of the examined WCs on the monthly unemployment rates were found. A negative (!) effect on the accumulated wages in France in the first and second quarter in 1998 was detected. For details see Table 2 and 3.

${ }^{16}$ Notwithstanding, it should be borne in mind that insignificant results could simply be due to the fact that in spite of all the media attention they attract, the sporting events are just too small in comparison to the large, diverse economy within which they take place (SZYMANSKI, 2002, p. 177). This applies particularly when they are considered against the background of the relatively high level of variance of economic time series that lead to increased significance demands.

17 Cf. BAADE \& MATHESON (2004) for the WC 1994 in the USA and HAGN \& MAENNIG (2008a, 2008b) examining the WCs 1974 and 2006 in Germany.

${ }_{18}$ For a comprehensive overview of empirical studies assessing the (short-, medium and longterm) effects of WCs and other comparable events, see Table 4 in appendix. The only long-term study on the effects of a sporting mega event finds positive evidence; see JASMAND \& MAENNIG (2008) on the Olympic Games 1972 in Munich.

19 More than $60 \%$ of the expenditure of the 12 WC 2006 stadia was financed by the clubs and other private investors. In addition, investments in the related infrastructure amounted to nearly US\$3 billion (MAENNIG \& BÜTTNER, 2006), despite the fact that the infrastructure that is relevant for large-scale sporting events (motorways and motorway junctions, railway platforms, car parks) already existed to a relatively high degree in Germany. 
stricting their construction works mainly to the reconstruction of existing stadiums, and by building only one new stadium (Stade de France) (SZYMANSKI, 2002). ${ }^{20}$

From an economic point of view, it has to be emphasized that these expenditures should not be equated with WC costs. If the stadiums remain in use after the WC, or would have been built or renovated without the occurrence of the WC, the WCrelated costs for stadiums should be understood as the consumption of resources in the form of losses in the value of the stadiums due to the tournament, usually described as depreciations in cost calculations. With regard to the amount of these costs, it can be noted that stadiums renovated or constructed for the WC 1974 in Germany did not fulfil the needs of the football clubs some 30 years later. Under the assumption of linear depreciation, the costs are some 3.3\% p.a. of the investment expenditures. This equals some $0.6 \%$ of WC-derived stadium costs on the basis of 10 weeks of exclusive use of the stadiums for the WC, including the periods of pre- and post-match operations. In the case of Germany 2006, these costs amount to US\$12 million, and should have been fully covered by the 2006 WC budget. ${ }^{21}$ A similar argument applies to transportation infrastructure if it was built in a sustainable way, i.e. provided benefits in connection with future uses of the stadiums.

If the stadium constructions and their expenditures cannot be charged to the WC in full, then this applies for the long-term benefits of the stadiums as well. This being said, it should be pointed out that new stadium structures or modernisations consistently engender a novelty effect: curiosity, but also the increase in comfort, improved view, and better atmosphere in new or renovated stadiums regularly lead to significantly higher spectator figures for the clubs, at least for a

${ }^{20}$ For the 2002 WC, South Korea spent nearly US\$ 2 billion, and Japan at least US\$ 4 billion for the stadia (BAADE \& MATHESON, 2004, p. 345).

${ }^{21}$ The organizing committee assigned about US\$2.2 million ( $€ 1.5$ million) to each stadium operator (DFB, 2006). In addition, each city received about US\$450,000 (€300,000) from the budget of the organizing committee, which, however, could not cover the city's costs for insurance, decorations, places for warming up, etc. 
period after these improvements..$^{22}$ In Germany, multivariate studies on all stadium-projects since 1963 regarding construction- and reconstruction isolated a rise in spectator numbers of about 2,700 , or some $10 \%$ per match (FEDDERSEN, MAENNIG, \& BORCHERDING, 2006). In select football stadiums, the novelty effect can even turn out to be markedly greater. The novelty value, which measures the additional receipts of the clubs or rather operators, can, in fact, be larger than the increase in attendance due to higher average price levels as a result of regularly expanded VIP and business seat areas. In addition, there are increased naming rights income, and income from other events which could not take place in less modern and prestigious stadiums.

While the direct economic impact of hosting such events has often been muted as discussed above, there is potential for exploiting the opportunity offered by large sporting events to create an architectural legacy via ambitious stadium architecture with lasting external effects for the regional economy. ${ }^{23}$ Success in this regard is often associated with so-called 'iconic' buildings. A clear definition of iconic buildings does not yet exist, but consideration of examples of this kind of building (e.g. the Sydney Opera House, the Guggenheim Museum in Bilbao, the Centre Pompidou in Paris, the Munich Olympic Stadium) do reveal certain common design characteristics: they display an architecture that, at least at the time of planning, was regarded as highly innovative, often apparently impractical and non-functional, but which was nevertheless unique and striking. The planning is often so unconventional that citizens unite in their resistance to it, resistance which, however, gradually gives way to a feeling of regional pride, inspiration and identification. In every case, the innovative design helped the building to succeed in becoming a landmark and part of the memorable character of their cities, which, in turn, succeed in 'getting their name on the world map', i.e. achieving the desired image effects (MAENNIG \& SCHWARTHOFF, 2006). Iconic buildings

${ }^{22}$ Cf. e.g. NOLL (1974), COFFIN (1996), OUIRK \& FORT (1992), KAHANE \& SHMANSKE (1997), CLAPP \& HAKES (2005) for the USA.

${ }^{23}$ Cf. MAENNIG (2006). For an econometric analysis of the effects of sport arenas on the regional economy see TU (2005) and AHLFELDT \& MAENNIG (2007a, 2007b). 
provide an aesthetic focal point for a city and could become a springboard for other urban developments and recreational facilities, which are, in turn, attractive for locals as well as international tourists.

Despite the accepted impact of iconic architecture (also referred to as 'signature architecture') the opportunity to aim for not only an optimization of the management efficiencies of professional sport clubs, but also for a particularly attractive, spectacular, iconic stadium to benefit each city, has been widely missed in recent stadium-projects. The architecture of the German WC-stadiums, while it is freely noted that many technical innovations and creative architectural ideas are bound up in the stadiums, overall, can be at best described as "functional". Germany 2006 did not generate unique new constructions and iconic architectural features with trans-regional significance, with the possible exception of the $\mathrm{Mu}$ nich Allianz Arena. It, however, was situated too far from the city centre to generate a positive effect for Munich in the foreseeable future. ${ }^{24}$ The evaluation of the French WC-stadiums is similar.

However, the "functional" design of stadiums should not be attributed to European club managers. They have the task of maximizing the income for their teams. For this, they must confine their endeavours to whatever is necessary to keep fans content. It is not their business to participate in municipal or regional politics, to make their architecture interesting from the point of view of the cityscape, or to achieve external effects for the regional economy, from which their budgets do not profit. Responsibility is left to the local authorities and their policy makers, who have to bear the additional costs of ambitious architecture (and, where applicable, better location). An increased level of positive economic effects emanating from stadiums thus in some cases, requires public funding.

${ }^{24}$ For the role of the (central) location of stadiums on city development, see particularly NELSON $(2001,2002)$ and SANTO (2005). 


\subsection{International Perception and Feel-good Effects for Residents}

Hosting a major sporting event like the WC might also be associated with effects that are often presumed either to be hardly measurable, or 'intangible'. Thus, WCs are regularly regarded as a possibility for self-marketing and image-building, which are expected to produce lasting improvements for the host nation's competitive environment. The successful execution of a mega-event provides the opportunity to demonstrate organisational and technological know-how, and to showcase the hospitality and the beauty of the country.

One possibility for assessing such image-effects is provided by the 'Anholt Nation Brands Index' (NBI), which evaluates the nation's brand image of developed and developing countries. Nations are classified quarterly in a worldwide poll regarding their cultural, political, commercial and human assets, investment potential and tourist appeal. The results are combined to produce an aggregate ranking. The NBI, which was started in 2005, shows a clear rise in the international perception of Germany as a result of the WC. The erstwhile image abroad of Germany as "hard and cold [...] not a nation much associated with warmth, hospitality, beauty, culture, or fun" (ANHOLT, 2006) was improved through the WC in all criteria that constitute the NBI. The greatest increase in approval was scored by the statement or question 'This country excels in sport'. Figure 5 shows the trends in selected questions that were presented with a scale of 6 (very good, complete agreement) to 1 (poor, no agreement). Figure 6 shows that after the World Cup, Germany has captured the second place in the NBI rank system, after ranking - on average - on 5th position in the quarters before.

Such results demonstrate the opportunity of image gains through hosting a major sporting event. ${ }^{25}$ The impact of WCs on the image of their hosts might heavily depend on the quality of their presentations in public as likeable, hospitably, progressive and as a capable (business) location. Various factors such as smooth operations during the event, the granting of security, and appropriate PR- and mar-

${ }^{25}$ Due to the available data, it was not possible to test statistical significance. 
keting-activities (MAENNIG \& PORSCHE, 2008) will thereby influence the imageeffects of subsequent WCs.

The 'non-use effect' also has to be considered: the benefit for the host countries' populations of the event taking place in their neighbourhood, even if they themselves do not visit the stadium. Reasons for benefits without experiencing the tournament in the stadiums might be, among others, the free and relaxed atmosphere during the WC, or increased topics of conversation. ${ }^{26}$ Quantitative ex ante preliminary and ex post studies on large sporting events mentioned so far have often neglected the value of this effect, also called the 'feelgood effect'. Only a few studies attempt, through a survey of payment reserves (willingness to pay), to evaluate this phenomenon of benefiting from (sporting) events without active attendance at the stadium. ${ }^{27}$ Nevertheless the results of a corresponding study regarding the WC 2006 show that this effect can have great significance: HEYNE, MAENNIG, \& SÜßMUTH (2007) determine that before the WC 2006, only one out of five Germans had a positive willingness to pay (WTP) for the WC to take place in Germany. On average, the WTP was US\$6.32 (€4.26) per person, which, with 82 million inhabitants, corresponds to some US-\$518 million. After the WC, $42.6 \%$ of Germans had a positive WTP, and the average was US\$15.88 (€10.07), amounting to US\$1.3 billion for the whole country. ${ }^{28}$ Since only a few of the 82 million Germans themselves had tickets to attend a stadium for a WC match, the willingness

${ }^{26}$ The magnitude of this effect might be strongly influenced by the 'public viewing' in the fanparks which makes the expression 'non-use' questionable.

27 JOHNSON \& WHITEHEAD (2000) study the willingness of people to pay for two stadium projects in Lexington, Kentucky, even if they do not visit the stadiums. ATKINSON et al. (2008) evaluate the British WTP for the Olympic Games in London 2012.

${ }^{28}$ HEYNE, MAENNIG, \& SÜßMUTH (2007) report that the increase in the willingness to pay is attributable above all to a change of attitude in those who, before the WC, were not willing to pay. After the WC, an increased willingness to pay was expressed particularly among East Germans, but also among low-skilled persons. HEYNE, MAENNIG, \& SÜßMUTH (2007) conclude that major sporting events have a characteristic 'experience value'; consumers cannot correctly estimate the quality of an event before their first experience of it, and hence, cannot predict their willingness to pay for it. 
to pay can be interpreted as a 'non-use effect'. This "intangible" effect is this amongst the most significant economic effects of the WC $2006 .^{29}$

To sum up, for a more thorough evaluation of the effects arising from WCs (and other major sporting events), more consideration should be given to the likelihood of (measurable) effects that are frequently given less attention in descriptions of WC-effects, such as the novelty effect and possible externalities of stadiums, the public image effect for the host nations and the feelgood effect amongst the residents.

\section{South Africa 2010 - Additional Challenges and Chances ${ }^{30}$}

There is no doubt that analyses of former WCs and other major sporting events provide a context for estimating the potential risks and benefits for South Africa 2010. However, European structures differ from South Africa's, which suggests that South Africa might have to cope with additional difficulties in some areas, but also might experience larger economic benefits in other fields through hosting the FIFA WC 2010.

\subsection{Additional Challenges for South Africa}

To start with, it has to be mentioned that South Africa plans to invest heavily to host the WC 2010. Ten stadiums are planned in nine host cities, all of which possess the minimum capacity of 40,000 spectators as required by the World Football Association FIFA. Five stadiums (Soccer City and Ellis Park in Johannesburg, Royal Bafokeng in Rustenberg, Loftus Versfeld in Pretoria and Free State in Bloemfontein) will be adapted to FIFA's quality requirements via modernisation measures. Another five stadiums (Cape Town, Durban, Nelspruit, Polokwane, Port Elizabeth) will be newly built. The information in Table 1 indicates a total investment of US\$ 1.38 billion on stadiums for which the government is almost exclu-

29 Although this might induce South African attempts to quantify the feel-good effect by ex ante polls, one should bear in mind that ex ante WTP might be substantially biased downward.

${ }^{30}$ This chapter heavily draws on MAENNIG \& DU PLESSIS (2007a). 


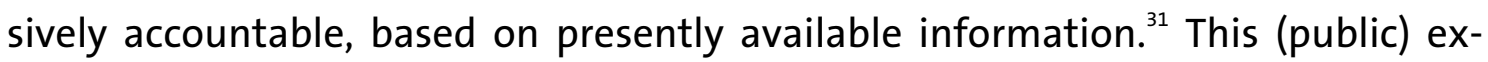
penditure stands in contrast to potentially only moderate possibilities for posttournament usage of the new large stadiums. ${ }^{32}$ The exceptions are Ellis Park in Johannesburg and Loftus Versfeld in Pretoria, both of which are home to some of the largest football and rugby teams. The future of the new stadium in Cape Town remains unclear if the provincial rugby team is unwilling to relocate from their present venue at Newlands. Under these circumstances, it is understandable that there is hardly any private financing for the WC-stadiums in South Africa, and that they would not have been built without the WC tournament. ${ }^{33}$ In this case, the investment expenditure is equal or at least similar to investment costs, leading to problematic benefit/cost ratios. ${ }^{34}$

A factor that might raise the costs of hosting the WC in South Africa unexpectedly is the current state of their business cycle and property market. The South African economy is presently experiencing its longest post-War expansion, but in recent

${ }^{31}$ This is sharply higher than the US\$ 112 million that the South African delegation budgeted for stadium investment at the time of the tournament bid (i.e. during 2004) (FIFA, 2004, p. 65) and is much closer to most of the experiences in relation to former WCs. Cf. MAENNIG \& DU PLESSIS (2007a) for a survey of the change in the budgeted amount for investment in stadia and related infrastructure that has been substantially increased by the South African government since 2004.

${ }^{32}$ Although there is considerable local interest in soccer, the attendance at soccer matches, even in the first league, is comparatively low at around 5,000 on average. In the German Bundesliga, average attendance during the $2006 / 07$ season was 40,000 per match (N.N., 2008c) and in the French Ligue 1, this value 20,500 per match (N.N., 2008b). However, it should be noted that the underuse of new facilities is a reality for the 20 stadia built for the WC 2002 in South Korea and Japan, which today are mainly used for informal markets and such, because there is little use for them by the Japanese and the Korean premier leagues, see FINER (2002), UNTERREINER (2006) and HORNE (2004).

${ }^{33}$ A recent, though modest, exception is the US\$27.1 million (ZAR 185 million) finance package provided by the South African investment bank Investec to meet the shortfall in the City of Cape Town's budget for the new Green Point stadium (VAN DER WESTHUIZEN, 2007). Conversion on the basis of the ZAR/US\$-exchange of 15 January 2008 (6.81554 ZAR/US\$).

${ }^{34}$ However, it should be emphasized that at least some of the South African stadium-projects are likely to create lasting external effects for the regional economy, leading to better benefit/cost ratios in the long-term (cf. section 3.2). The almost exclusive usage of public funds will probably have allowed for the consideration of urban planning aspects to this extent. Moreover STURGESS \& BRADY (2006) point out the possibility of a general rise in the popularity of soccer as a consequence of hosting a WC. 
months, imbalances both domestically (large and rising household debt) and externally (a large current account deficit) have grown more acute, and policy makers at the South African Reserve Bank have begun tightening monetary policy. Furthermore, the result of this long upswing and the associated property boom is that building costs have risen sharply (FUNKE, KISSMER, \& WAGNER, 2006; PABST, 2007). Under these circumstances, there are realistic concerns about the ability of the local construction industry to manage the construction, or rather the completion, of the stadiums, the Gautrain, the King Shaka airport in Durban, and the De Hoop Dam (BUNDESAGENTUR FÜR AUßENWIRTSCHAFT, 2007a, 2007b; CAPAZORIO, 2006).

Two other conditions that are also likely to cause particular problems in South Africa where the economy is currently growing at a rate of five percent per year: during the entire period of the tournament, no construction work is permitted in the host cities. In addition, the cities have to provide reserve capacity for electricity generation to compensate for any capacity shortfalls, a recurring problem in South Africa (N.N., 2008d). ${ }^{35}$

\subsection{Additional Chances for South Africa}

South Africa faces not only additional difficulties due to the prevailing conditions in this nation, but also extra benefits in other areas (MAENNIG \& DU PLESSIS, 2007a).

First, the 'couch potato effect' mentioned in section 2.1 is less likely to occur in South Africa. Due to different hospitality and 'going out' behaviours of football fans in South Africa, spending might be higher instead of lower if they stayed at home and invited friends to watch TV together. This may lead to a positive impetus on the local economies such as retail business and the hotel and catering industry, which might induce employment effects as well, at least in the short term.

${ }^{35}$ The additional consumption of electricity by the stadia, media centers, and hospitality areas was calculated at about 13 million KW for the WC 2006, BUNDESMINISTERIUM DES INNEREN (2006, p. 15). 
Second, the usual negative crowding-out effect on regular tourism of large sporting events referred to in section 2.1 might not occur because the WC happens during the low season for tourism in South Africa. This raises potentials for additional receipts from tourism and employment-effects in the tourism- and leisureindustry not only in the short-term, but also for the long-term to the extent that the country succeeds in presenting itself as an attractive tourist destination for future trips. Moreover, WC-tourists are likely to stay longer in South Africa (i.e. spend more) due to the long distance they had to overcome for the tournament in most cases. ${ }^{36}$

Third, most of the econometric studies on sporting events and sport facilities (for an overview see Table 4) are related to the USA and European countries, which enjoy ample provision of sports facilities. In Germany, for example, there are 127,000 sports venues, including 400 multi-purpose sports halls with spectator capacities of at least 3,000. Given that sports venues are also subject to the law of diminishing returns, low-level returns are to be expected at most. For countries such as South Africa that do not have a comparably dense provision of sporting facilities at their disposal, unsatisfactory economic consequences may not directly apply.

Fourth, although at present, only a few South African sporting events apart from rugby are capable of drawing maximum capacity crowds, this will presumably change in future. The South African economy is enjoying its longest post-War upswing and poverty indices have shown a rapid decline in poverty. For example, the headcount poverty rate declined from $51.4 \%$ in 2001 to $43.2 \%$ in 2006 , while mean incomes of the poorest $20 \%$ of society increased on average about $7.2 \%$ p.a. during this period. Furthermore, there is evidence for a reduction in the depth and severity of poverty (REPUBLIC OF SOUTH AFRICA, 2007, p. 23 et seqq.). Higher in-

${ }^{36}$ For the WC 2006 in Germany, an average sojourn time of around 10 days had been assumed for foreign WC-tourists (KURSCHEIDT \& RAHMANN, 1999; MADEJA, 2005). Ex ante estimates for the WC 2010 calculate with a mean length of stay of 15 days of visitors from abroad (GRANT THORNTON, 2004). 
comes for poor South Africans are auspicious for WC related activities, as the majority of the country's football fans are poor.

Finally, it has to be considered that the sport venues built or reconstructed for past WCs hardly stimulated any positive effects to the regional economy because they were not built with this aim in mind. The aim during planning was usually to maximise the profit margins of the professional clubs, rather than urban development. ${ }^{37}$ In South Africa, there is evidence that the WC might be used as a vehicle to attempt to induce positive urban economic effects: The new King Senzangakhona Stadium in Durban is being designed as an 'iconic' building with a 30 storey arch stretching its entire length (JONES, 2006b; SAPA, 2006). The relevant design is not limited to the stadium itself, but is embedded in a design concept for the entire urban region, thus ensuring that the stadium positively affects Durban's economic viability. Not just in Durban, but also in other host cities of the next WC, the architectural plans (published so far) do indeed seem different from the functional stadium projects of former WCS (MAENNIG \& SCHWARTHOFF, 2006). ${ }^{38}$ As elsewhere, though, there is some resistance to 'signature' projects: the residents of Greenpoint in Cape Town are evidently less willing to tolerate, much less to pay for, an iconic stadium. Indeed, pressure from local residents has already resulted in an instruction to the architects to 'moderate' their design for the new stadium (SCHAUG, 2006). In this regard, it is desirable that some of the South African host cities which are large, dynamic, and important - but not yet internationally prominent - succeed in 'getting their name on the world map'. In conjunction with the South African stadium-projects, it should also be emphasized, that despite the public presence of a formal list of criteria used to determine the host cities and venues in South Africa, important criteria seem to have been the existing infrastructure (stadiums, transportation and tourist facilities) in major metropolitan areas, the geographical spread of stadiums across the nine provinces of South Africa and the goal of encouraging economic activity in under-

${ }^{37}$ It should once again be emphasised that the club managers bear less responsibility for these developments than the local authority decision-makers.

${ }^{38}$ See Figures 7 to 9 for views of the planned stadia in Durban, Port Elizabeth and Cape Town. 
developed rural areas in response to the large gap between urban and rural incomes and wealth in South Africa (MAENNIG \& DU PLESSIS, 2007b).

\section{Conclusion}

The analyses of the WCs held in France in 1998 and in Germany in 2006 agree with former empirical findings on the effects of large sporting events, namely that hardly any WCs and comparable events have positive impacts on tourism, employment and income. Nevertheless, we are less sceptical than other academics about the beneficial impact of South Africa 2010 based on five arguments. First, the 'couch potato effect' which diverts WC-addicted consumers from their normal consumption behaviours is less likely to occur in South Africa. Second, the usual negative crowding-out effect on regular tourism of large sporting events might not have its usual magnitude because the WC will happen during the low season for tourism in South Africa. Third, South Africa does not have a comparably dense provision of sporting facilities as North American or European countries. Fourth, South African stadium projects draw on the insights from urban economics with the aim of a more effective integration of stadiums with urban needs, which hold the promise of enhanced positive externalities. As was true for former WCs, South Africa may improve its international perception which in the long term may generate increased numbers of private and conference tourists, as well as attract external investors (JASMAND \& MAENNIG, 2008). This effect might be much stronger for South Africa than for former WC organising countries like the USA, Japan/Korea, France or Germany if South Africa is able to run the event smoothly and to maintain security. Given all this, fifth, the event benefit or feelgood utility might reach new record levels in football-addicted South Africa. 


\section{Apendix}

Tab. 1 Stadium Investments for the FIFA 2010 World Cup in South Africa

\begin{tabular}{|c|c|c|c|}
\hline City & $\begin{array}{c}\text { Expenditure (US\$ } \\
\text { millions) }\end{array}$ & $\begin{array}{c}\text { Capacity season } \\
2010 \\
\end{array}$ & Inhabitants (2004) \\
\hline \multicolumn{4}{|c|}{ New Stadiums } \\
\hline Cape Town & $403.1^{a, b}$ & $68,000^{c}$ & $2,984,885$ \\
\hline Durban & $278^{d}$ & $70,000^{\mathrm{e}}$ & $3,129,298$ \\
\hline Nelspruit & $118.8^{f}$ & $43,500^{g}$ & 484,245 \\
\hline Polokwane & $111.2^{\mathrm{h}, \mathrm{i}}$ & $45,000^{\mathrm{h}, \mathrm{i}}$ & 532,673 \\
\hline Port Elizabeth & $159.9^{j}$ & $40,000^{j}$ & $1,054,359$ \\
\hline \multicolumn{4}{|c|}{ Upgraded Stadiums } \\
\hline Bloemfontein & $34.1^{k}$ & $48,000^{\prime}$ & 655,332 \\
\hline $\begin{array}{c}\text { Johannesburg: Ellis } \\
\text { Park }\end{array}$ & $29.2^{\mathrm{m}}$ & $65,000^{\mathrm{m}}$ & $3,225,407$ \\
\hline $\begin{array}{c}\text { Johannesburg: Soccer } \\
\text { City }\end{array}$ & $208.5^{n}$ & $94,700^{n}$ & \\
\hline Pretoria & $25.7^{\circ}$ & $55,000^{\circ}$ & 1,531954 \\
\hline Rustenburg & $20.4^{p}$ & $45,000^{p}$ & 405,554 \\
\hline Total & 1388.9 & 574,200 & \\
\hline
\end{tabular}

Source: MAENNIG \& DU PLESSIS (2007a).

Notes: ${ }^{a}$ VAN DER WESTHUIZEN (2007), ${ }^{b}$ WEBB (2007), ' $Y E L D ~(2006),{ }^{d}$ WEST (2007), ${ }^{e}$ JONES

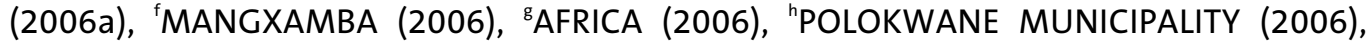
'LOUW (2006), 'MATAVIRE (2007), "'DLODLO (2007), 'DAILY DISPATCH (2007), ' 'SEALE

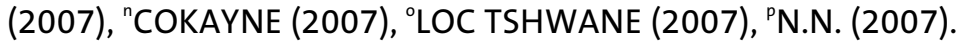

Fig. 1 Overnight Stays in Germany since 2000

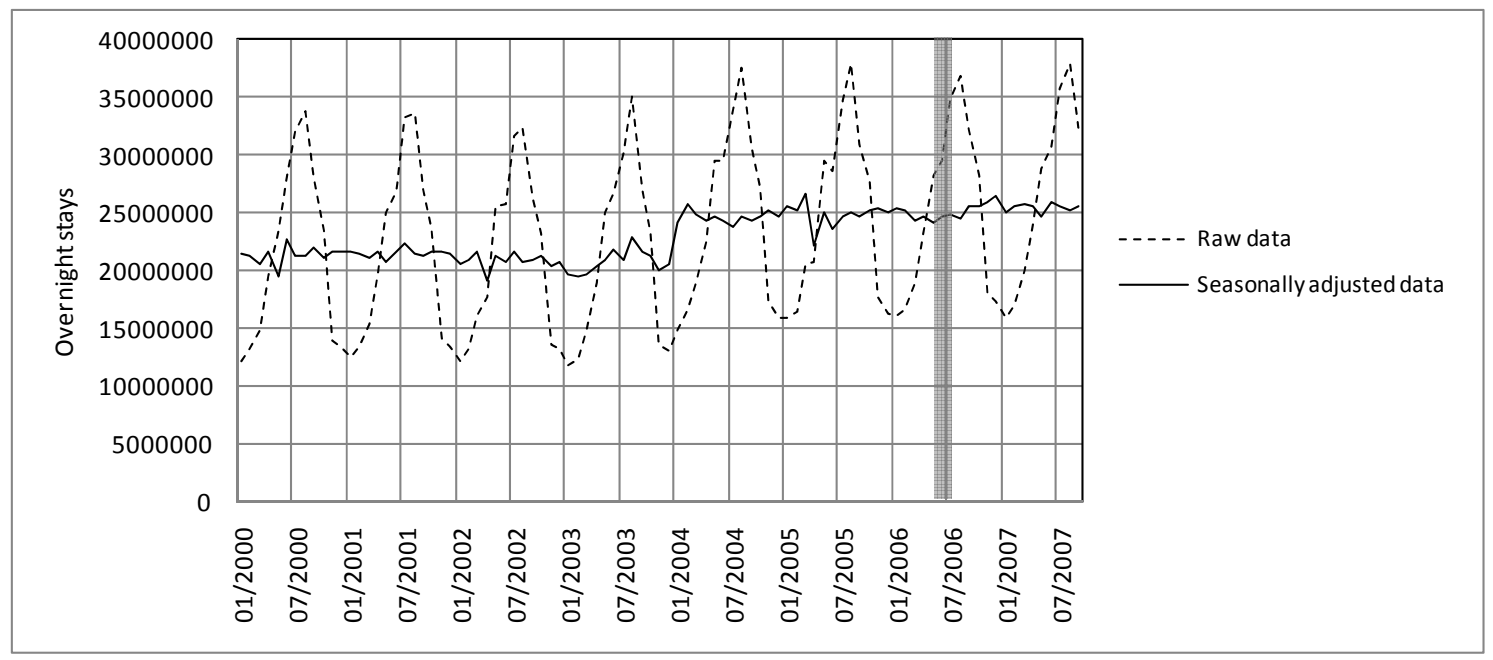

Source: EUROSTAT (2007). 
Fig. 2 Overnight Stays in Germany in the Years 2004 to 2006

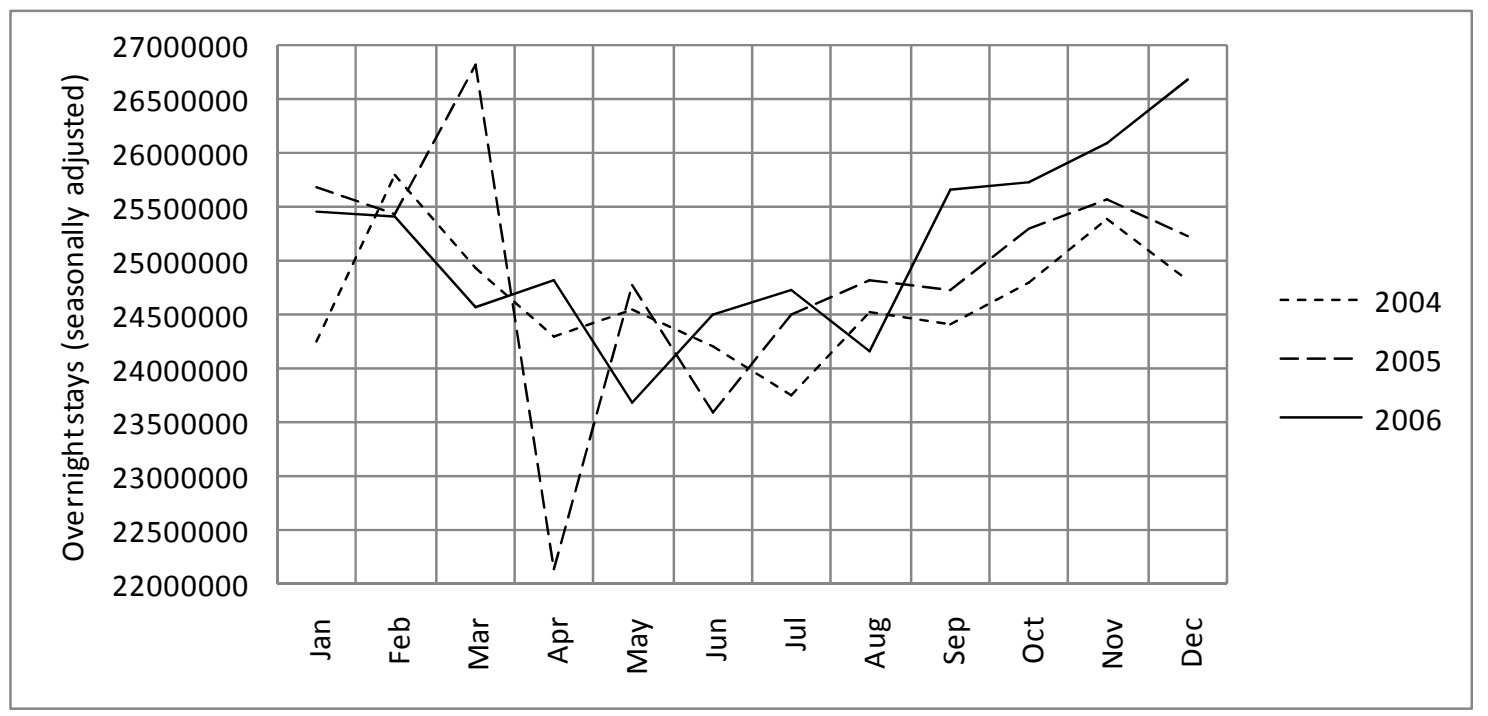

Source: EUROSTAT (2007).

Fig. 3 Tourism Receipts in Germany

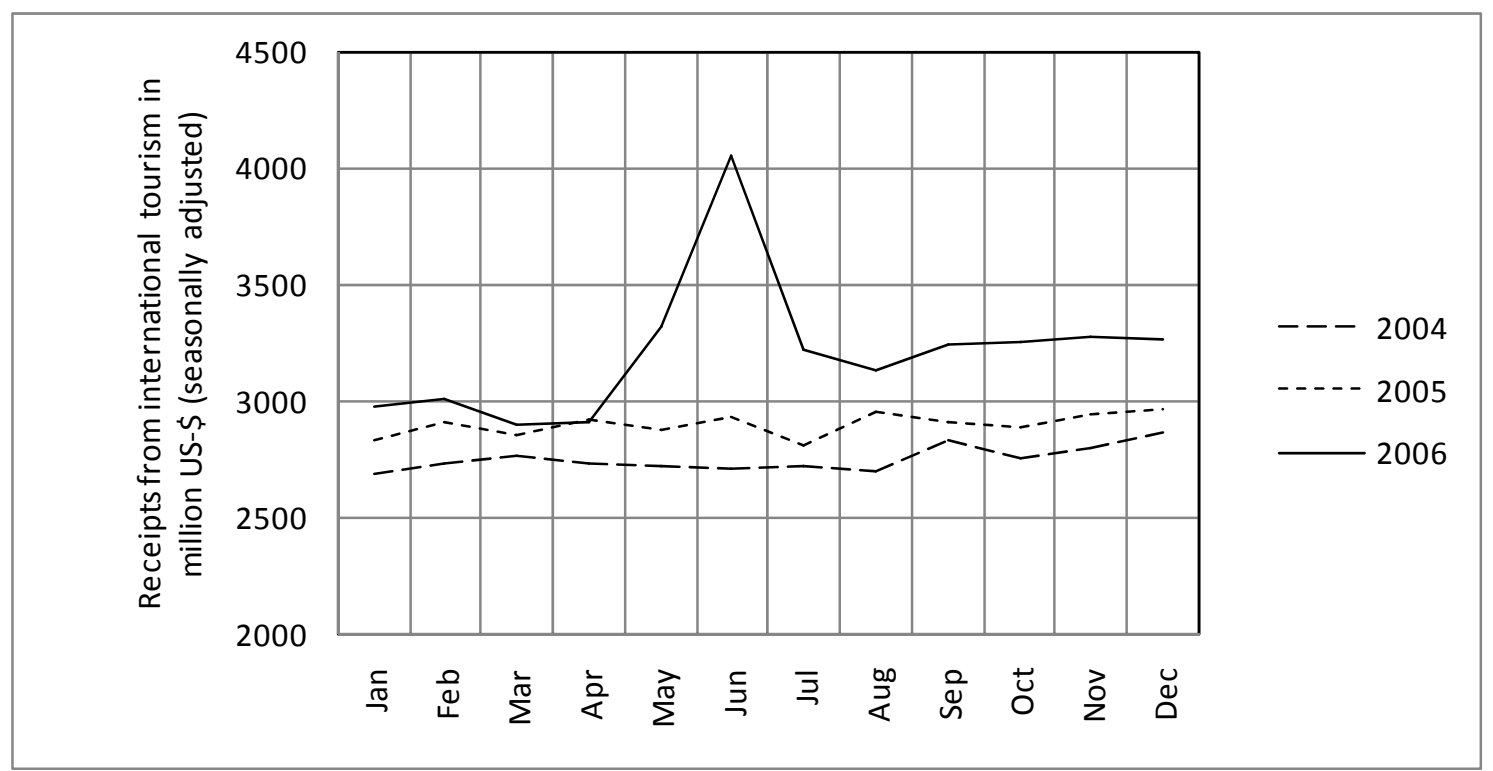

Source: DEUTSCHE BUNDESBANK (2007). 
Fig. 4 Percent Change in Retail Sales in Germany

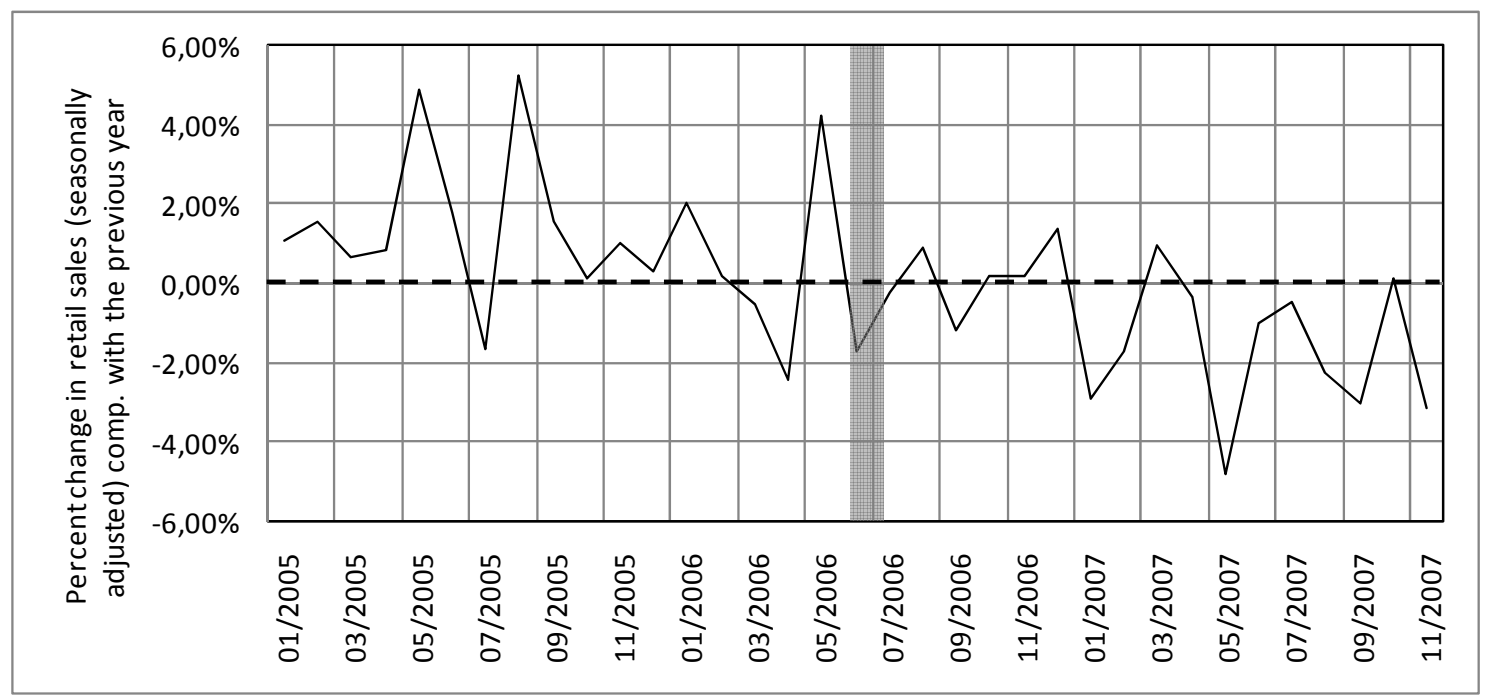

Source: EUROSTAT (2008).

Fig. 5 International Perception of Germany

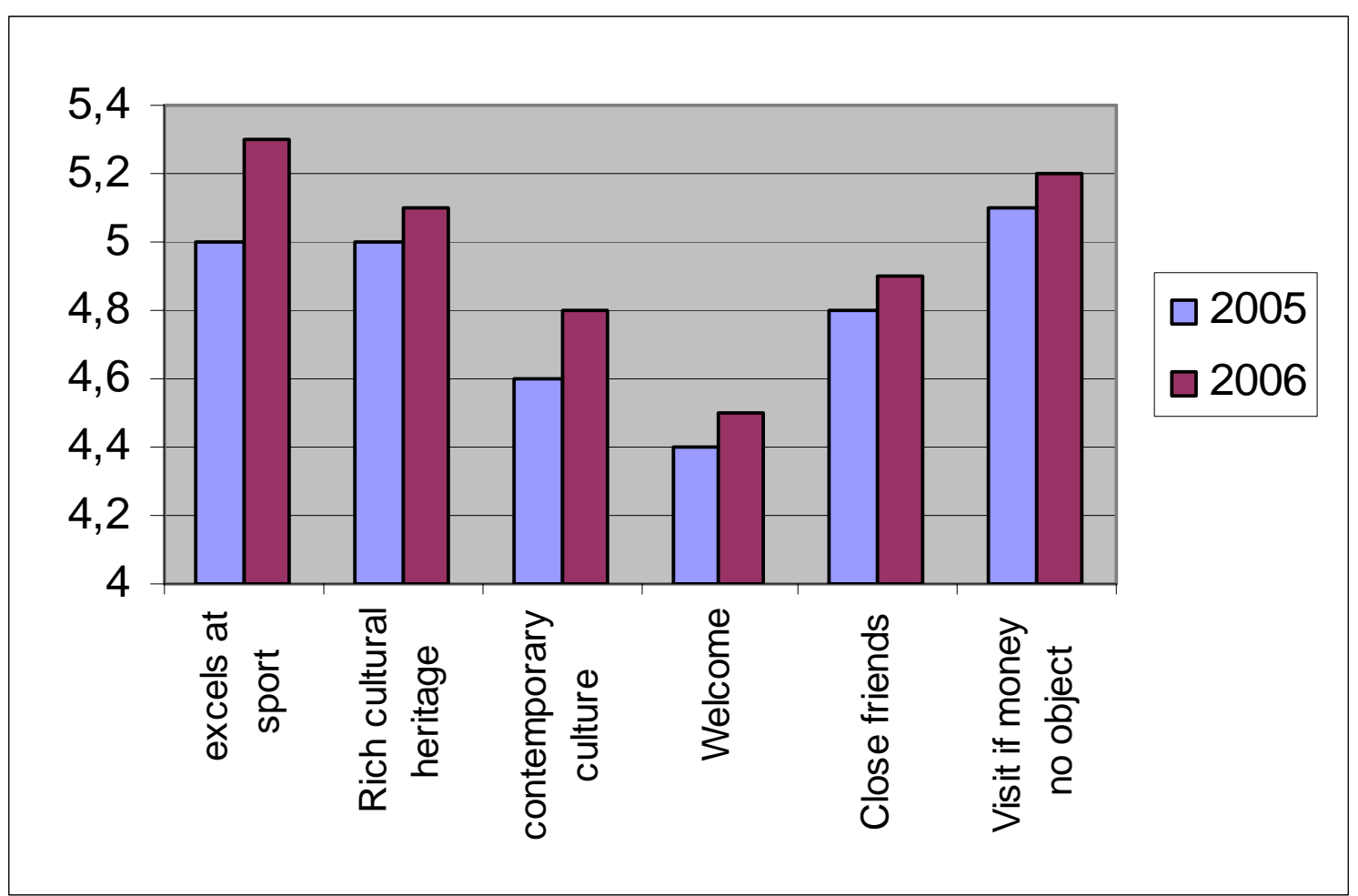

Notes: Wave 3/2005 and 3/2006 GMI-Anholt Nations Brand Index. 
Fig. 6 Anholt's Nation Brand Index - Rank of Germany

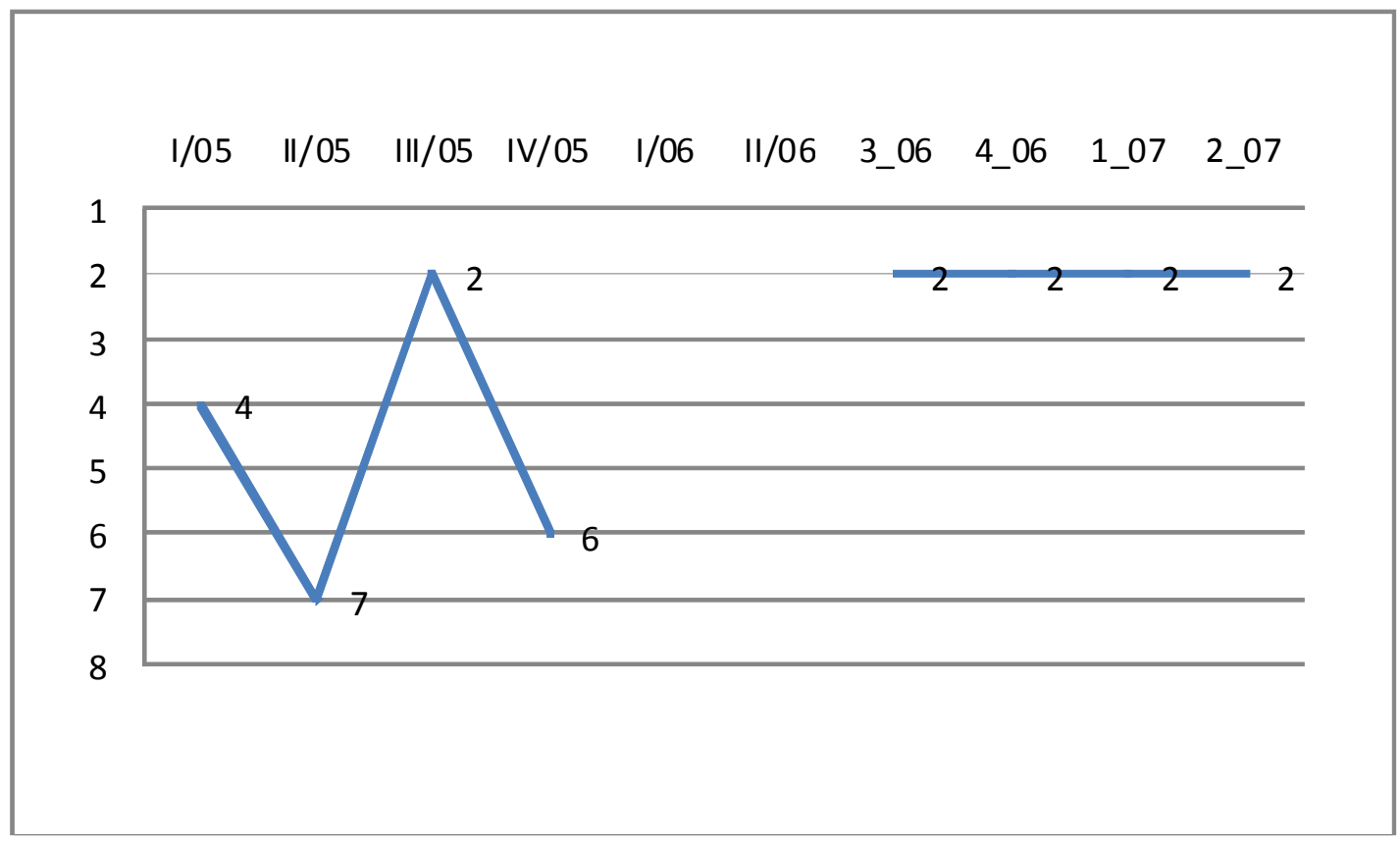

Source: Anholt's Nation Brand Index, various issues.

Tab. 2 Regression Results for Germany 2006

\begin{tabular}{|c|c|c|c|c|c|c|c|c|}
\hline Indicator & Constant & Trend & May 2006 & June 2006 & July 2006 & August 2006 & AR(1) & Adj. $R^{2}$ \\
\hline $\begin{array}{l}\text { Overnight stays } \\
\text { (total) }\end{array}$ & $\begin{array}{l}18997186 \\
(17.61264)\end{array}$ & $\begin{array}{l}31188.73 \cdots \\
(3.101197)\end{array}$ & $\begin{array}{l}-785171.2 \\
(-0.832531)\end{array}$ & $\begin{array}{l}-350895.8 \\
(-0.306210)\end{array}$ & $\begin{array}{l}-315721.0 \\
(-0.275513)\end{array}$ & $\begin{array}{l}-914851.2 \\
(-0.970019)\end{array}$ & $\begin{array}{l}0.850428 \cdots \\
(22.19700)\end{array}$ & 0.809675 \\
\hline $\begin{array}{l}\text { Overnight stays } \\
\text { (hotels) }\end{array}$ & $\begin{array}{l}11590403^{\cdots} \\
(81.71898)\end{array}$ & $\begin{array}{l}14331.89 \\
(10.45120)\end{array}$ & $\begin{array}{l}-256864.2 \\
(-0.876356)\end{array}$ & $\begin{array}{l}-564043.9 \\
(-1.634529)\end{array}$ & $\begin{array}{l}-308397.2 \\
(-0.893690)\end{array}$ & $\begin{array}{l}-467339.0 \\
(-1.594427)\end{array}$ & $\begin{array}{l}0.678265^{\cdots} \\
(12.01820)\end{array}$ & 0.869261 \\
\hline $\begin{array}{l}\text { Tourism receipts } \\
\text { (million } € \text { ) }\end{array}$ & $\begin{array}{l}2499.815^{\cdots} \\
(3.465890)\end{array}$ & $\begin{array}{l}-1.388046 \\
(-0.697925)\end{array}$ & $\begin{array}{l}234.5335 \\
(1.540278)\end{array}$ & $\begin{array}{l}686.6421 \cdots \\
(3.700421)\end{array}$ & $\begin{array}{l}82.29714 \\
(0.443514)\end{array}$ & $\begin{array}{l}-23.30944 \\
(-0.153084)\end{array}$ & $\begin{array}{l}0.880086 \cdots \\
(23.74302)\end{array}$ & 0.784282 \\
\hline $\begin{array}{l}\text { Tourism expendi- } \\
\text { ture (million } € \text { ) }\end{array}$ & $\begin{array}{l}12047.52 \cdots \\
(5.625940)\end{array}$ & $\begin{array}{l}-17.43161 \\
(-2.963072)\end{array}$ & $\begin{array}{l}-51.41688 \\
(-0.128126)\end{array}$ & $\begin{array}{l}-135.3734 \\
(-0.276528)\end{array}$ & $\begin{array}{l}-89.12482 \\
(-0.182056)\end{array}$ & $\begin{array}{l}-1003.040 " \\
(-2.499475)\end{array}$ & $\begin{array}{l}0.892961 \\
(25.95640)\end{array}$ & 0.890547 \\
\hline $\begin{array}{l}\text { Tourism service } \\
\text { balance (million } € \text { ) }\end{array}$ & $\begin{array}{l}-9449.868 \\
(-9.435874)\end{array}$ & $\begin{array}{l}15.91495 \\
(5.704452)\end{array}$ & $\begin{array}{l}218.5518 \\
(0.532124)\end{array}$ & $\begin{array}{l}591.4344 \\
(1.197678)\end{array}$ & $\begin{array}{l}122.3346 \\
(0.247727)\end{array}$ & $\begin{array}{l}708.0810 \\
(1.723943)\end{array}$ & $\begin{array}{l}0.776757 \\
(16.17854)\end{array}$ & 0.839132 \\
\hline $\begin{array}{l}\text { Retail sales index } \\
\text { (deflated) }\end{array}$ & $\begin{array}{l}97.97954 \cdots \\
(269.4771)\end{array}$ & $\begin{array}{l}0.017273 \cdots \\
(4.653059)\end{array}$ & $\begin{array}{l}4.233697 \\
(2.079154)\end{array}$ & $\begin{array}{l}1.185867 \\
(0.582257)\end{array}$ & $\begin{array}{l}-0.020461 \\
(-0.010044)\end{array}$ & $\begin{array}{l}2.107653 \\
(1.034420)\end{array}$ & & 0.150722 \\
\hline $\begin{array}{l}\text { Employment (in } \\
\text { thousands) }\end{array}$ & $\begin{array}{l}33506.99 \cdots \\
(7.191079)\end{array}$ & $\begin{array}{l}27.36336 \\
(1.810372)\end{array}$ & $\begin{array}{l}43.49724 \\
(1.023186)\end{array}$ & $\begin{array}{l}68.55073 \\
(1.316572)\end{array}$ & $\begin{array}{l}64.51089 \\
(1.238985)\end{array}$ & $\begin{array}{l}37.97352 \\
(0.893254)\end{array}$ & $\begin{array}{l}0.989824 \cdots \\
(106.3342)\end{array}$ & 0.996119 \\
\hline $\begin{array}{l}\text { Unemployment } \\
\text { rate }\end{array}$ & $\begin{array}{l}44.13698 \\
(0.341367)\end{array}$ & $\begin{array}{l}-0.110832 \\
(-0.403788)\end{array}$ & $\begin{array}{l}-0.140756 \\
(-1.164243)\end{array}$ & $\begin{array}{l}-0.181135 \\
(-1.222883)\end{array}$ & $\begin{array}{l}-0.221137 \\
(-1.492947)\end{array}$ & $\begin{array}{l}-0.060759 \\
(-0.502563)\end{array}$ & $\begin{array}{l}0.994240 \cdots \\
(72.11161)\end{array}$ & 0.972098 \\
\hline Indicator & Constant & Trend & Q1/2006 & Q2/2006 & Q3/2006 & Q4/2006 & AR(1) & Adj. $R^{2}$ \\
\hline $\begin{array}{l}\text { Wages (accumu- } \\
\text { lated) (million } € \text { ) }\end{array}$ & $\begin{array}{l}242740.2^{\cdots} \\
17.53209\end{array}$ & $\begin{array}{l}799.1710 \\
3.179061\end{array}$ & $\begin{array}{l}-184.4707 \\
-0.091870\end{array}$ & $\begin{array}{l}-228.6385 \\
-0.092966\end{array}$ & $\begin{array}{l}-531.1471 \\
-0.216061\end{array}$ & $\begin{array}{l}-2301.251 \\
-1.147059\end{array}$ & $\begin{array}{l}0.917903^{\cdots} \\
15.51840\end{array}$ & 0.974437 \\
\hline $\begin{array}{l}\text { Consumption priv. } \\
\text { households. (const. } \\
\text { prices) (million } € \text { ) }\end{array}$ & $\begin{array}{l}279976.7 \cdots \\
(13.91678)\end{array}$ & $\begin{array}{l}364.6284 \\
(1.059772)\end{array}$ & $\begin{array}{l}3526.899^{\circ} \\
(1.744105)\end{array}$ & $\begin{array}{l}2036.274 \\
(0.824041)\end{array}$ & $\begin{array}{l}2308.018 \\
(0.933996)\end{array}$ & $\begin{array}{l}3933.037^{\circ} \\
(1.944889)\end{array}$ & $\begin{array}{l}0.914054 \cdots \\
(14.92133)\end{array}$ & 0.964283 \\
\hline
\end{tabular}

Notes: $t$-satistics in parenthese. "=significant on $10 \%$-confidence level, " = significant on $5 \%$ confidence level, "' = significant on $1 \%$-confidence level. 
Tab. 3 Regression Results for France 1998

\begin{tabular}{|c|c|c|c|c|c|c|c|c|}
\hline Indicator & Constant & Trend & May 1998 & June 1998 & July 1998 & August 1998 & $\operatorname{AR}(1)$ & Adj. $R^{2}$ \\
\hline $\begin{array}{l}\text { Overnight stays } \\
\text { (hotels) }\end{array}$ & $\begin{array}{l}6969445 \\
(57.92764)\end{array}$ & $\begin{array}{l}22686.26 \cdots \\
(19.63276)\end{array}$ & $\begin{array}{l}286799.9 \\
(1.148658)\end{array}$ & $\begin{array}{l}-419412.3 \\
(-1.429022)\end{array}$ & $\begin{array}{l}-332718.0 \\
(-1.134471)\end{array}$ & $\begin{array}{l}-201594.0 \\
(-0.808593)\end{array}$ & $\begin{array}{l}0.676228 \\
(12.01950)\end{array}$ & 0.955836 \\
\hline $\begin{array}{l}\text { Retail sales index } \\
\text { (deflated) }\end{array}$ & $\begin{array}{l}79.39335 \cdots \\
(204.0218)\end{array}$ & $\begin{array}{l}0.2595011^{\cdots} \\
(67.35218)\end{array}$ & $\begin{array}{l}-0.874272 \\
(-0.531230)\end{array}$ & $\begin{array}{l}-2.555178 \\
(-1.512997)\end{array}$ & $\begin{array}{l}0.296414 \\
(0.175580)\end{array}$ & $\begin{array}{l}-0.179671 \\
(-0.109339)\end{array}$ & $\begin{array}{l}0.225155 \cdots \\
(2.783995)\end{array}$ & 0.980535 \\
\hline $\begin{array}{l}\text { Unemployment } \\
\text { rate }\end{array}$ & $\begin{array}{l}25.56383 \\
(0.680108)\end{array}$ & $\begin{array}{l}-0.061386 \\
(-0.791309)\end{array}$ & $\begin{array}{l}-0.040423 \\
(-0.522083)\end{array}$ & $\begin{array}{l}-0.080635 \\
(-0.850307)\end{array}$ & $\begin{array}{l}-0.020635 \\
(-0.217597)\end{array}$ & $\begin{array}{l}-0.060423 \\
(-0.780390)\end{array}$ & $\begin{array}{l}0.994799 \cdots \\
(104.5547)\end{array}$ & 0.995141 \\
\hline Indicator & Constant & Trend & Q1/1998 & Q2/1998 & Q3/1998 & Q4/1998 & AR(1) & Adj. $R^{2}$ \\
\hline $\begin{array}{l}\text { Tourism receipts } \\
\text { (million } € \text { ) }\end{array}$ & $\begin{array}{l}5178.813 \\
(17.47683)\end{array}$ & $\begin{array}{l}87.92485 \cdots \\
(9.579082)\end{array}$ & $\begin{array}{l}-64.79600 \\
(-0.116604)\end{array}$ & $\begin{array}{l}-124.3224 \\
(-0.202799)\end{array}$ & $\begin{array}{l}-44.10685 \\
(-0.072001)\end{array}$ & $\begin{array}{l}16.30871 \\
(0.029389)\end{array}$ & $\begin{array}{l}0.457089 \\
(3.472522)\end{array}$ & 0.863675 \\
\hline $\begin{array}{l}\text { Tourism expendi- } \\
\text { ture (million } € \text { ) }\end{array}$ & $\begin{array}{l}2837.686 \cdots \\
(32.07257)\end{array}$ & $\begin{array}{l}68.60980 \cdots \\
(24.87503)\end{array}$ & $\begin{array}{l}-73.01171 \\
(-0.356083)\end{array}$ & $\begin{array}{l}-80.99046 \\
(-0.372620)\end{array}$ & $\begin{array}{l}-29.94475 \\
(-0.137902)\end{array}$ & $\begin{array}{l}-86.47416 \\
(-0.422535)\end{array}$ & $\begin{array}{l}0.331987^{*} \\
(2.353270)\end{array}$ & 0.965424 \\
\hline $\begin{array}{l}\text { Tourism service } \\
\text { balance (million } € \text { ) }\end{array}$ & $\begin{array}{l}2355.258 \\
(10.47393)\end{array}$ & $\begin{array}{l}18.15040 " \\
(2.584103)\end{array}$ & $\begin{array}{l}-15.65987 \\
(-0.025639)\end{array}$ & $\begin{array}{l}-16.33376 \\
(-0.025992)\end{array}$ & $\begin{array}{l}25.25237 \\
(0.040226)\end{array}$ & $\begin{array}{l}133.3074 \\
(0.218737)\end{array}$ & $\begin{array}{l}0.219915 \\
(1.529735)\end{array}$ & 0.126410 \\
\hline $\begin{array}{l}\text { Consumption priv. } \\
\text { households. (const. } \\
\text { prices) (million } € \text { ) }\end{array}$ & $\begin{array}{l}140840.8 \\
(62.36192)\end{array}$ & $\begin{array}{l}1238.185 \% \\
(26.02029)\end{array}$ & $\begin{array}{l}10.23122 \\
(0.008505)\end{array}$ & $\begin{array}{l}-145.7786 \\
(-0.100817)\end{array}$ & $\begin{array}{l}236.7535 \\
(0.164215)\end{array}$ & $\begin{array}{l}678.9966 \\
(0.567793)\end{array}$ & $\begin{array}{l}0.744138 \cdots \\
(8.101989)\end{array}$ & 0.995547 \\
\hline $\begin{array}{l}\text { Employment (in } \\
\text { thousands) }\end{array}$ & $\begin{array}{l}11561.10 \\
(8.433907)\end{array}$ & $\begin{array}{l}61.67884 \\
(4.074823)\end{array}$ & $\begin{array}{l}-0.730096 \\
(-0.013966)\end{array}$ & $\begin{array}{l}57.57918 \\
(0.898997)\end{array}$ & $\begin{array}{l}20.79379 \\
(0.324668)\end{array}$ & $\begin{array}{l}-33.92087 \\
(-0.648904)\end{array}$ & $\begin{array}{l}0.966722 \\
(33.87437)\end{array}$ & 0.996366 \\
\hline $\begin{array}{l}\text { Wages (accumu- } \\
\text { lated) (million } € \text { ) }\end{array}$ & $\begin{array}{l}110781.6 \\
(14.73202)\end{array}$ & $\begin{array}{l}1990.530 \\
(14.65441)\end{array}$ & $\begin{array}{l}-2206.246 " \\
(-2.151477)\end{array}$ & $\begin{array}{l}-2598.285 \\
(-2.075338)\end{array}$ & $\begin{array}{l}-1261.056 \\
(-1.007274)\end{array}$ & $\begin{array}{l}478.8642 \\
(0.467001)\end{array}$ & $\begin{array}{l}0.892294 \\
(14.92858)\end{array}$ & 0.998378 \\
\hline
\end{tabular}

Notes: $t$-satistics in parenthese. $=$ significant on $10 \%$-confidence level, $"=$ significant on $5 \%$ confidence level, ${ }^{\prime \prime}=$ significant on $1 \%$-confidence level. 


\begin{tabular}{|c|c|c|c|c|c|c|c|c|c|c|}
\hline 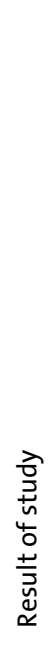 & 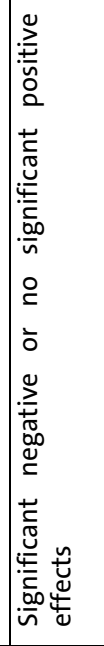 & 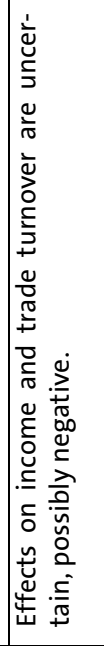 & 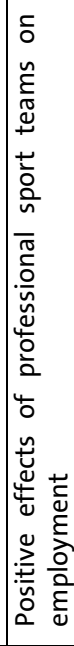 & 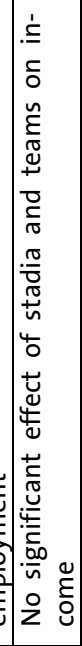 & 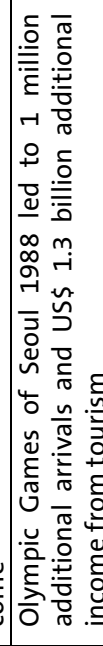 & 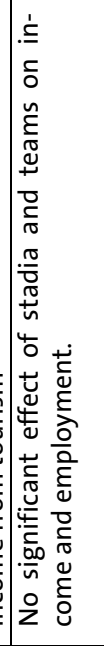 & 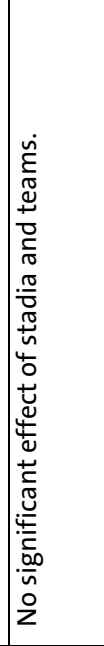 & 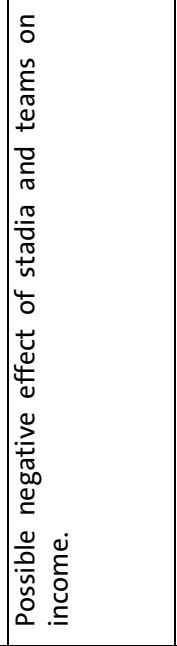 & 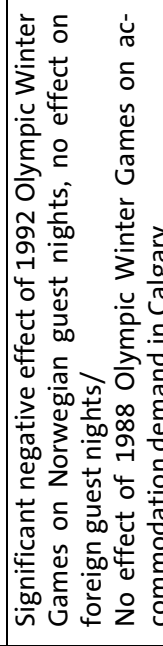 & 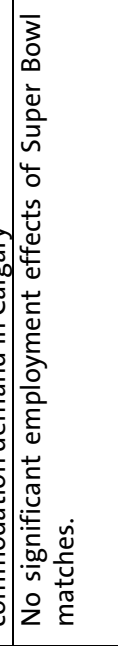 \\
\hline 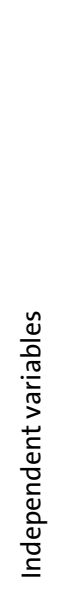 & 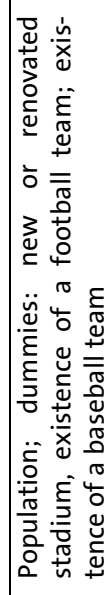 & 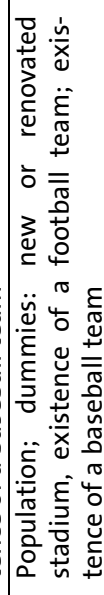 & 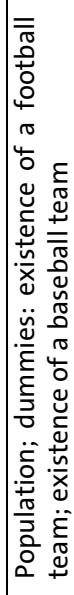 & 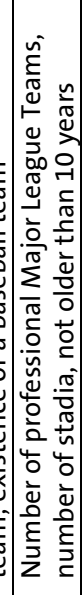 & 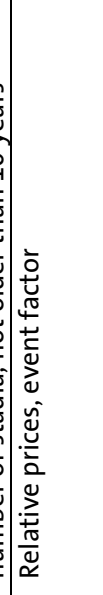 & 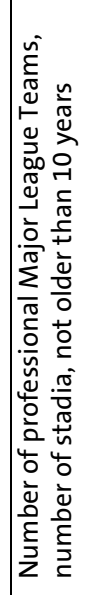 & 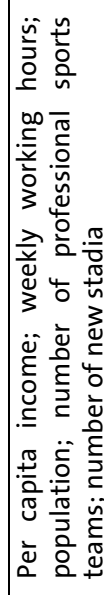 & 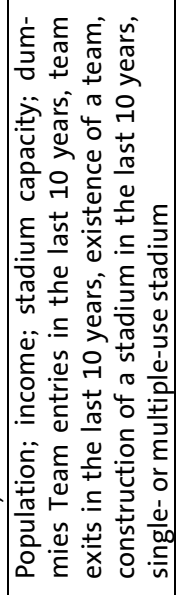 & 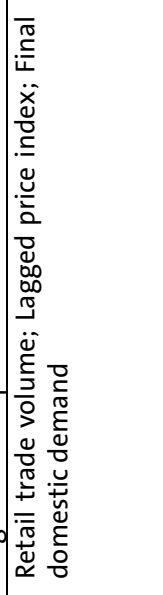 & 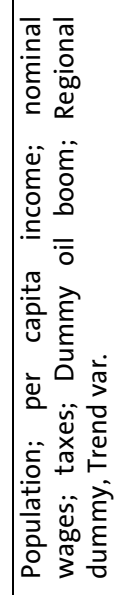 \\
\hline 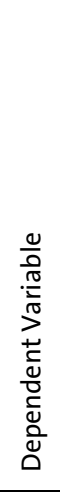 & 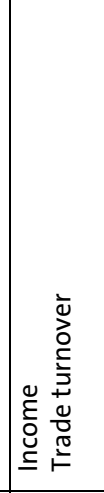 & 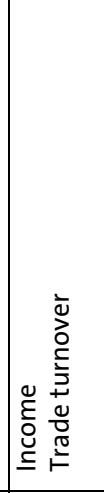 & 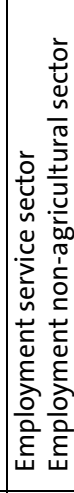 & 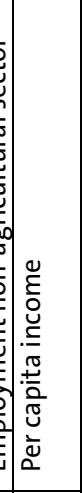 & 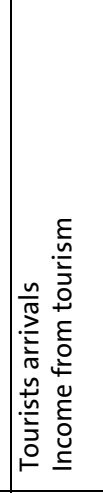 & 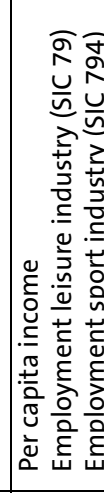 & 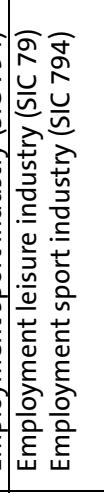 & 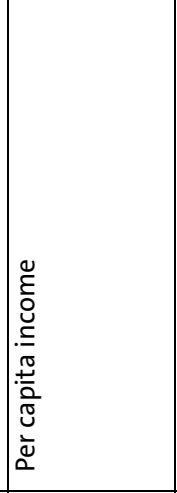 & 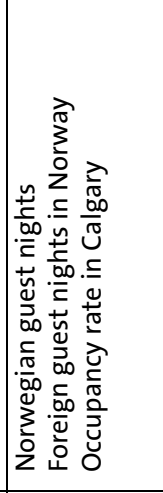 & 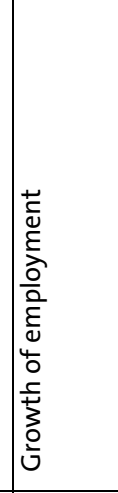 \\
\hline $\begin{array}{l}\stackrel{0}{\circ} \\
\overline{\bar{z}} \\
\alpha\end{array}$ & 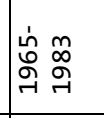 & 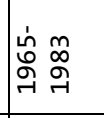 & 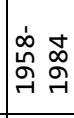 & 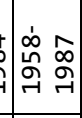 & 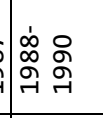 & 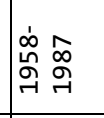 & 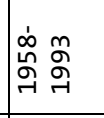 & જ่ & 穴 & 角 \\
\hline 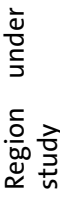 & 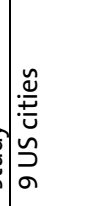 & 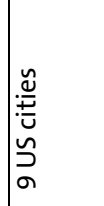 & 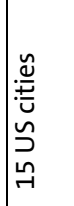 & 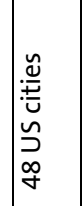 & 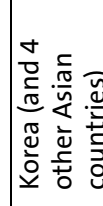 & 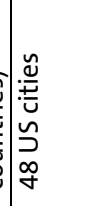 & 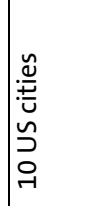 & 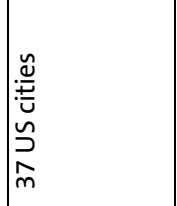 & 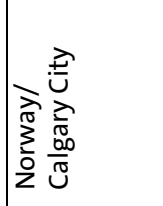 & 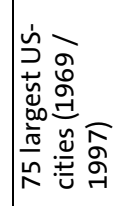 \\
\hline 离 & 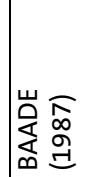 & 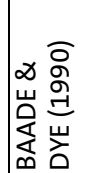 & 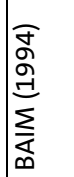 & 崖盾 & 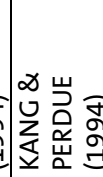 & 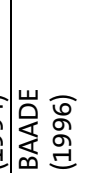 & 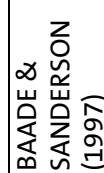 & 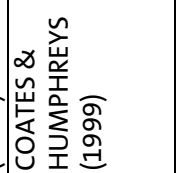 & 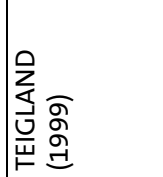 & 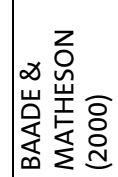 \\
\hline
\end{tabular}




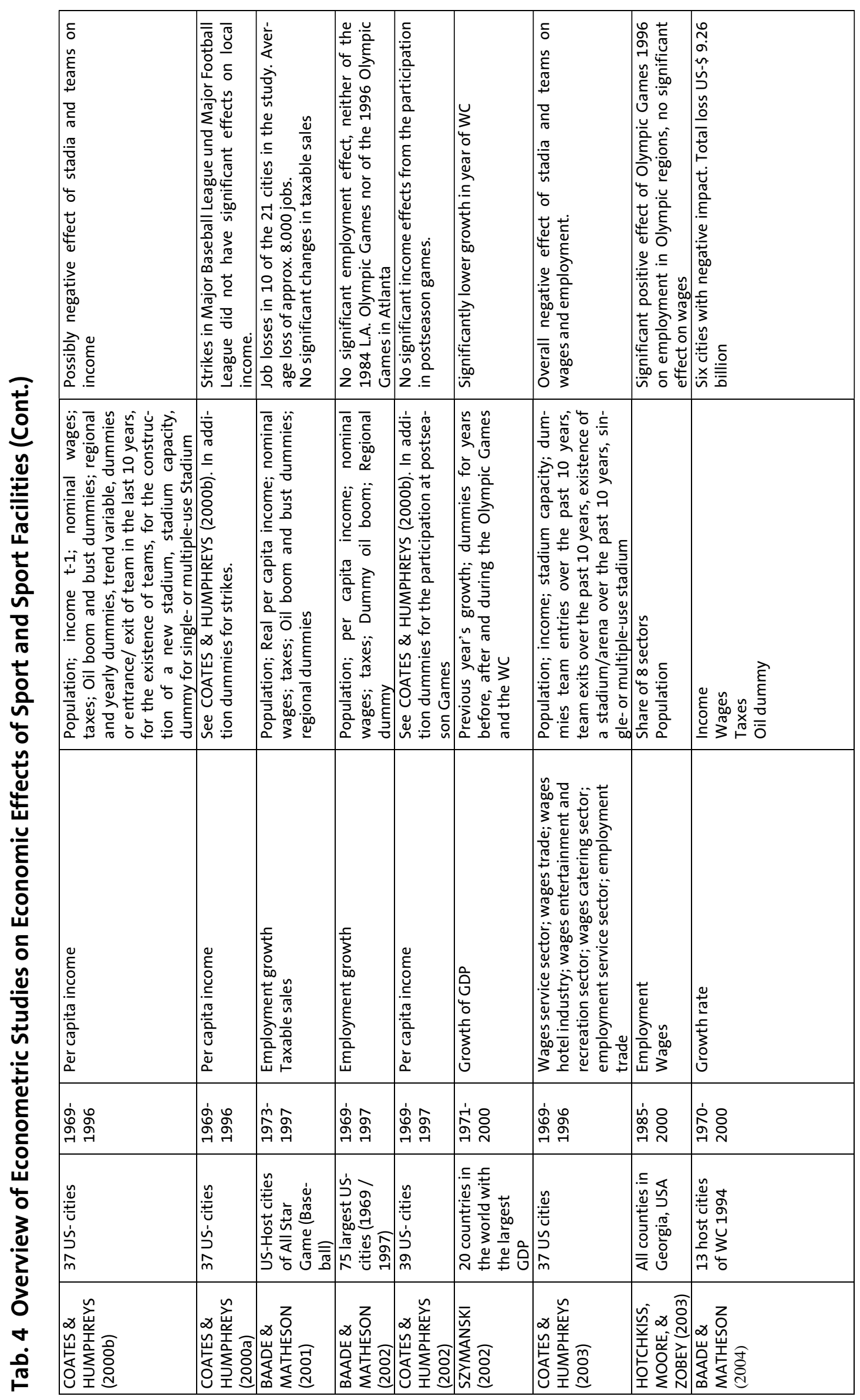




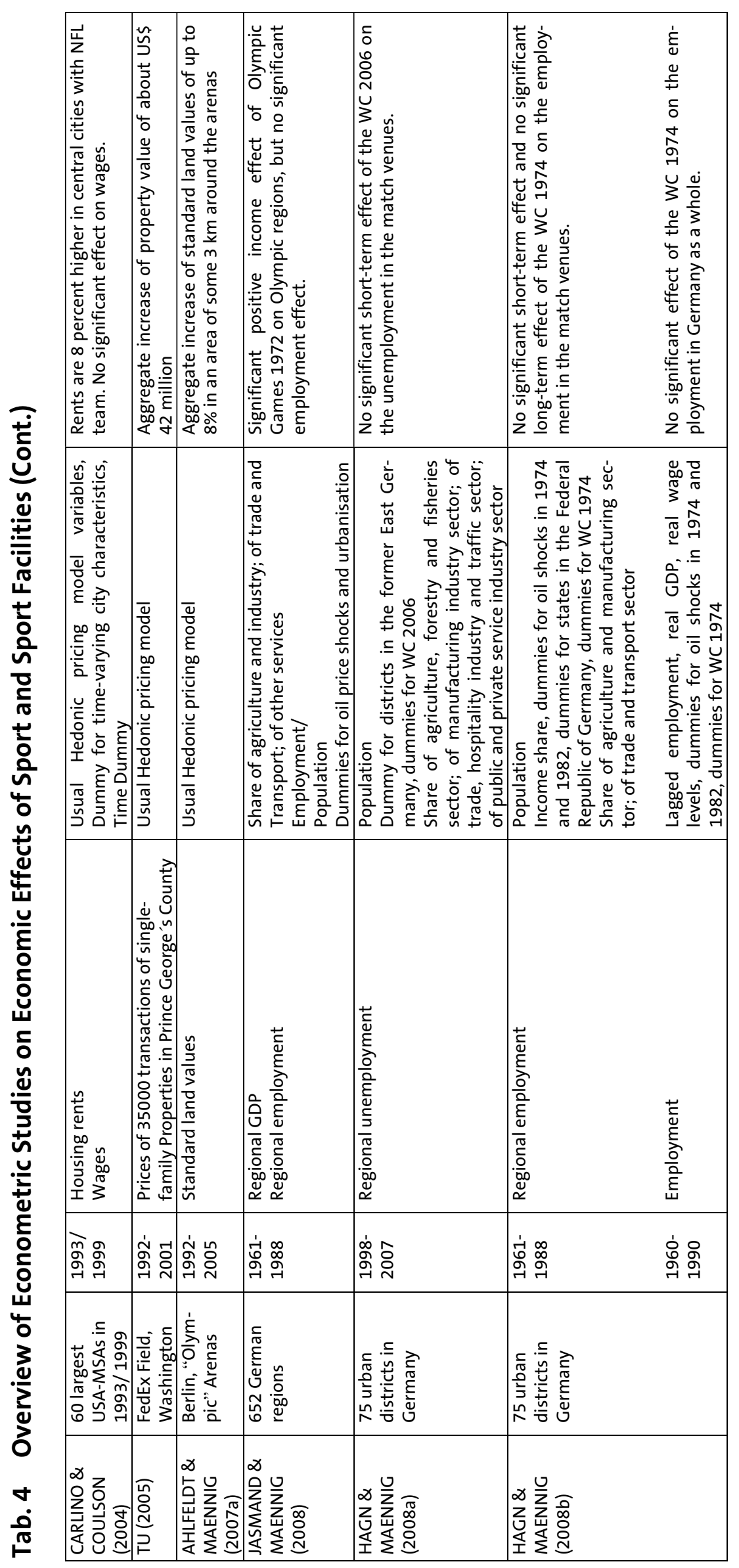




\section{Literature}

AFRICA, R. (2006). A World Cup Sod is Turned in Nelspruit. Diamond Fields Advertiser, Johannesburg, 15 December 2006, p. 15.

AHLFELDT, G., \& MAENNIG, W. (2007a). The Impact of Sports Arenas on Land Values: Evidence from Berlin. Hamburg Contemporary Economic Discussions, No. 03.

AHLFELDT, G., \& MAENNIG, W. (2007b). The Role of Architecture on Urban Revitalisation: The Case of "Olympic Arenas" in Berlin-Prenzlauer Berg. Hamburg Contemporary Economic Discussions, No. 01 [forthcoming in Urban Studies]

ANHOLT, S. (2006). Anholt Nation Brands Index: Israel's International Image. Quarterly Report, No.3/2006, GMI: Seattle.

ATKINSON, G., MOURATO, S., SZYMANSKI, S., \& OZDEMIROGLU, E. (2008). Are We Willing to Pay Enough to 'Back the Bid'?: Valuing the Intangible Impacts of London's Bid to Host the 2012 Summer Olympic Games. Urban Studies, 45(2), 419-444.

BAADE, R. A. (1987). Is There an Economic Rationale for Subsidizing Sports Stadiums? Heartland Policy Study 13.

BAADE, R. A. (1994). Stadiums, Professional Sports, and Economic Development: Assessing the Reality. The Heartland Institute Policy Study, 62.

BAADE, R. A., \& DYE, R. F. (1990). The Impact of Stadiums and Professional Sports on Metropolitan Area Development. Growth and Change, 21(2), 1-14.

BAADE, R. A., \& MATHESON, V. (2000). An Assessment of the Economic Impact of the American Football Championship, the Super Bowl, on Host Communities. Reflets et Perspectives, 39(2-3), 35-46.

BAADE, R. A., \& MATHESON, V. (2001). Home Run or Wild Pitch? Assessing the Economic Impact of Major League Baseball's All-Star Game. Journal of Sports Economics, 2(4), 307-327.

BAADE, R. A., \& MATHESON, V. (2002). Bidding for the Olympics: Fool's Gold? In C. P. BARROS, M. IBRAHIMO \& S. SZYMANSKI (Eds.), Transatlantic Sport: The Comparative Economics of North American and European Sports (pp. 127-151). Cheltenham, U.K. and Northampton, Mass.: Edward Elgar.

BAADE, R. A., \& MATHESON, V. (2004). The Quest for the Cup: Assessing the Economic Impact of the World Cup. Regional Studies, 38(4), 343-354.

BAADE, R. A., \& SANDERSON, A. R. (1997). The Employment Effect of Teams and Sports Facilities. In R. G. NOLL \& A. ZIMBALIST (Eds.), Sports, Jobs, and Taxes: The Economic Impact of Sports Teams and Stadiums (pp. 92-118). Washington, D.C.: Brookings Institution Press.

BAIM, D. V. (1994). The Sports Stadium as a Municipal Investment. Westport and London: Greenwood Press.

BOB, U., SWART, K., \& TURCO, D. (2006). Crime and Sport Tourism Events in South Africa: Implications for the 2010 World Cup. Valencia: Noos Institute.

BUNDESAGENTUR FÜR AUßENWIRTSCHAFT (2007a). Branche Kompakt - Südafrikas Bauwirtschaft (Branch Content - South Africa Construction Industry) [Electronic Version]. Retrieved 21 January 2008 from http://bfai.de/DE/Content/_SharedDocs/LinksDatenbankabfragen/mkt-branche-kompakt-bauwirtschaft-integrator.html. 
BUNDESAGENTUR FÜR AUßENWIRTSCHAFT (2007b). Datenbank Länder und Märkte, gute Perspektiven für Südafrikas Bauwirtschaft (Good Perspectives for South Africa's Construction Library) [Electronic Version]. Retrieved 21 January 2008 from http://www.bfai.de/DE/Content/_SharedDocs/Links-Einzeldokumente-Datenbanken /fachdokument.html?fldent=MKT200706298001.

BUNDESMINISTERIUM DES INNEREN (2006). Die Welt war zu Gast bei Freunden. Bilanz der Bundesregierung Zur FIFA Fußball-Weltmeisterschaft 2006 (The World Has Been a Guest at Friends. Resumé of the German Government on the WC 2006). Berlin.

CAPAZORIO, B. (2006). Experts Warn of Critical Shortage in SA Construction Industry. The Herald. Port Elizabeth, 9 October.

CARLINO, G., \& COULSON, N. E. (2004). Compensating Differentials and the Social Benefits of the NFL. Journal of Urban Economics, 56(1), 25-50.

CLAPP, C. M., \& HAKES, J. K. (2005). How Long a Honeymoon? The Effect of New Stadiums on Attendance in Major League Baseball. Journal of Sports Economics, 6(3), 237-263.

COATES, D., \& HUMPHREYS, B. R. (1999). The Growth Effects of Sport Franchises, Stadia, and Arenas. Journal of Policy Analysis and Management, 18(4), 601-624.

COATES, D., \& HUMPHREYS, B. R. (2000a). The Economic Consequences of Professional Sports, Strikes and Lockouts. Southern Economic Journal, 67(3), 737-747.

COATES, D., \& HUMPHREYS, B. R. (2000b). The Stadium Gambit and Local Economic Development. The Cato Review of Business and Government, 23(2), 15-20.

COATES, D., \& HUMPHREYS, B. R. (2002). The Economic Impact of Postseason Play in Professional Sports. Journal of Sports Economics, 3(3), 291-299.

COATES, D., \& HUMPHREYS, B. R. (2003). The Effect of Professional Sports on Earnings and Employment in the Services and Retail Sectors in Us Cities. Regional Science and Urban Economics, 33(2), 175-198.

COFFIN, D. A. (1996). If You Build It, Will They Come? Attendance and New Stadium Construction. In J. L. FIZEL, E. F. GUSTAFSON \& L. H. HADLEY (Eds.), Baseball Economics: Current Research. Westport, Conn.: Praeger.

COKAYNE, R. (2007, 18 January 2007). Deadline Cloud Looms over World Cup Stadium Revamp. Star, p. 15.

DAILY DISPATCH $(2007,19.01 .2007)$. Bloemfontein Stadtium on Track. Daily Dispatch, p. 10.

DEUTSCHE BUNDESBANK (2006). Der WM-Effekt bei den Reiseverkehrseinnahmen in Deutschland (The WC-Effect on the Receipts from Tourist Travel in Germany). Monthly report, November 43.

DEUTSCHE BUNDESBANK (2007). Zeitreihen Datenbank: Dienstleistungsverkehr mit dem Ausland.

DFB (2006). FIFA WM 2006 auch wirtschaftlich ein großer Erfolg (WC 2006 Also Economically a Big Success). Retrieved 14.09., 2006, from http://www.dfb.de/news/ display.php?id=9673\&lang=D\&anfrage $=\& k a t=n e w s \&$ navig $=\&$ seitentitel=News

DIHT (2006). Fußball-WM 2006: Auswirkungen auf die Unternehmen. Ergebnisse einer DIHK-Unternehmensbefragung. Retrieved 24 July, 2006, from http://www.dihk.de/ index.html?/inhalt/themen/standortpolitik/konjunktur/index.html

DLODLO, C. (2007, 16.01.2007). Stadion Kos Munisipaliteit Net R24m. Volksblad, p. 13. 
EUROSTAT (2007). Nights Spent by Non-Residents - Monthly Data, Hotels and Similar Establishments, Other Collective Accommodation Establishments, Total.

EUROSTAT (2008). Retail Trade, except of Motor Vehicles, Motorcycles and Trade at Filling Stations.

FEDDERSEN, A., MAENNIG, W., \& BORCHERDING, M. (2006). The Novelty Effect of New Football Stadia: The Case of Germany. International Journal of Sport Finance, 1(3), $174-188$.

FIFA (2004). Inspection Group Report for the 2010 FIFA World Cup. Geneva: FIFA.

FINER, J. (2002). The Grant Illusion. Far Eastern Economic Review, 165(9), $32-36$.

FUNKE, N., KISSMER, F., \& WAGNER, H. (2006). International Lessons for the Property Price Boom in South Africa. South African Journal of Economics, 74(2), 205-214.

GRANT THORNTON (2004). 2010 Soccer World Cup Facts You Should Know [Electronic Version]. Retrieved 22 June 2006 from http://www.gauteng.net/research/pdf/ soccer1.pdf.

HAGN, F., \& MAENNIG, W. (2008a). Labour Market Effects of the 2006 Soccer World Cup in Germany. Applied Economics (in press).

HAGN, F., \& MAENNIG, W. (2008b). Short-Term to Long-Term Employment Effects of the Football World Cup 1974 in Germany. Labour Economics (in press).

HEYNE, M., MAENNIG, W., \& SÜßMUTH, B. (2007). Mega-Sporting Events as Experience Goods. Hamburg Contemporary Economic Discussions, No. 05.

HORNE, J. (2004). The Global Game of Football: The 2002 World Cup and Regional Development in Japan. Third World Quarterly, 25(7), 1233-1244.

HOTCHKISS, J. L., MOORE, R. E., \& ZOBAY, S. M. (2003). Impact of the 1996 Summer Olympic Games on Employment and Wages in Georgia. Southern Economic Journal, 69(3), 691-704.

JASMAND, S., \& MAENNIG, W. (2008). Regional Income and Employment Effects of the 1972 Munich Olympic Summer Games. Regional Studies (in press).

JOHNSON, B. K., \& WHITEHEAD, J. C. (2000). Value of Public Goods from Sports Stadiums: The CVM Approach. Contemporary Economic Policy, 18(1), 48-58.

JONES, S. (2006a). Premier Officiates on Final Demolition of Soccer Stadium. Witness. Durban, 26 July 2006, p. 3.

JONES, S. (2006b). Stadium of Dreams. Durban Unveils Its World Cup Plans. Natal Witness. Durban, 16 June 2006, p. 1.

KAHANE, L., \& SHMANSKE, S. (1997). Team Roster Turnover and Attendance in Major League Baseball. Applied Economics, 29(4), 425-431.

KANG, Y.-S., \& PERDUE, R. (1994). Long-Term Impact of a Mega-Event on International Tourism to the Host Country: A Conceptual Model and the Case of the 1988 Seoul Olympics. Journal of International Consumer Marketing, 6(3/4), 205-225.

KURSCHEIDT, M., \& RAHMANN, B. (1999). Local Investment and National Impact: The Case of the Football World Cup 2006 in Germany. Retrieved 20. January 2008, from http://www.ruhr-uni-bochum.de/fussball/KurscheidtRahmann.pdf.

LOC TSHWANE (2007). Information Received Via E-Mail. 
LOUW, M. (2006). Polokwane Bou Nuwe Stadion Vir 2010. Beeld. Johannesburg, 15 August 2006, p. 4.

MADEJA, A. (2005). FIFA Fußball-Weltmeisterschaft in Deutschland. Ergebnisse im Rahmen der Besucherbefragung anlässlich der EM 2004 (Fifa Soccer World Cup in Germany. Results of the Visitors Survey on the Occassion of the EURO 2004). Reutlingen: IHK Akademie.

MAENNIG, W. (1998). Möglichkeiten und Grenzen von Kosten-Nutzen-Analysen im Sport. Sportwissenschaft, 28(3), 311-327.

MAENNIG, W. (2006). Ikonen statt Schüsseln [Icons Instead of "Bowls"]. Immobilienmanger, 7-8, 32-34.

MAENNIG, W. (2007). One Year Later: A Re-Appraisal of the Economics of the 2006 Soccer World Cup. Hamburg Working Paper Series in Economic Policy, No. 10.

MAENNIG, W., \& BÜTTNER, N. (2006). Infrastrukturinvestitionen bei Sportstadienneu-, um- und -ausbauten: Der Fall der Fußball-WM 2006. In E. THÖNI, M.-P. BÜCH \& E. KORNEXL (Eds.), Effektivität Und Effizienz Öffentlicher Sportförderung. Schorndorf: Hofmann.

MAENNIG, W., \& DU PLESSIS, S. (2007a). World Cup 2010: South African Economic Perspectives and Policy Challenges Informed by the Experience of Germany 2006. Contemporary Economic Policy, 25(4), 578-590.

MAENNIG, W., \& DU PLESSIS, S. (2007b). World Cup 2010: South African Economic Perspectives and Policy Challenges Informed by the Experience of Germany 2006. Hamburg Contemporary Economic Discussions, No. 4.

MAENNIG, W., \& PORSCHE, M. (2008). The Feel-Good Effect at Mega Sport Events - Recommendations for Public and Privat Administration Informed by the Experience of the Fifa World Cup 2006. Hamburg Contemporary Economic Discussions, No. 18.

MAENNIG, W., \& SCHWARTHOFF, F. (2006). Stadium Architecture and Regional Economic Development: International Experience and the Plans of Durban, South Africa. In D. TORRES (Ed.), Major Sport Events as Opportunity for Development. Valencia.

MANGYAMBA, S. (2006). Stadium Construction Daunting. Cape Argus, p. 5.

MATAVIRE, M. (2007, 23 February 2007). Stadium Contract Signed, Sealed. The Herald, p. 1.

N.N. (2006a). Bahn und Telekom übertreffen ihre WM-Prognosen (National Railway and Telecom Outperform Their WC-Forecasts). Der Tagesspiegel, 8 July 2006, p. 16.

N.N. (2006b). Ein Land im Bierrausch (A Country in a Beer Flush). Frankfurter Allgemeine Zeitung, 29 June 2006, p. 20.

N.N. (2007). FIFA Impressed with Royal Bafokeng Sports Palace [Electronic Version]. Retrieved 4 April 2007 from http://www.sabcnews.com/sport/soccer/0,2172,144 155,00.html.

N.N. (2008a). 2010 Soccer World Cup Facts You Should Know... [Electronic Version]. Retrieved 22 January 2008 from http://www.capetownroutesunlimited.com/ $? q=$ node $/ 14$.

N.N. (2008b). Average Attendance in the French Football League (Ligue 1) [Electronic Version]. Retrieved 13 January 2008 from http://www.weltfussball.de/zuschauer.php? Thema $=46 \&$ Liga $=11 \&$ s_id $=2047 \& x=11 \& y=8 \&$ modus $=1$. 
N.N. (2008c). Average Attendance in the German Football League (1. Bundesliga) [Electronic Version]. Retrieved 13 January 2008 from http://www.weltfussball.de/ zuschauer.php?Thema=3\&Liga $=1 \&$ s id $=1961 \& \mathrm{x}=11 \& \mathrm{y}=7 \&$ modus $=1$.

N.N. (2008d). Fußball-WM bei Kerzenschein? (Soccer-WC by Candelight?) [Electronic Version]. Badische Zeitung. Retrieved 21 January 2008 from http://www.badischezeitung.de/nachrichten/welt/54,51-19510726.html.

NELSON, A. C. (2001). Prosperity or Bligth? A Question of Major League Stadia Locations. Economic Developmet Quarterly, 15(3), 255-265.

NELSON, A. C. (2002). Locating Major League Stadiums Where They Can Make a Difference: Empirical Analysis with Implications for All Major Public Venues. Public works management policy, 7, 98- 114.

NOLL, R. G. (1974). Attendance and Price Setting. In R. G. NOLL (Ed.), Government and the Sports Business (pp. 115-157). Washington, DC: Brookings Institution.

PABST, G. (2007). Südafrika Intern, II/2007. Retrieved 24 January 2007, from www.pabstconsult.com/?download=Newsletter\%2011.2007.pdf.

POLOKWANE MUNICIPALITY (2006). 2010 Projects's Business Plan. Polokwane: Municipality of Polokwane.

QUIRK, J. P., \& FORT, R. D. (1992). Pay Dirt: The Business of Professional Team Sports. Princeton, NJ: Princeton Univ. Press.

REPUBLIC OF SOUTH AFRICA (2007). Development Indicators Mid-Term Review [Electronic Version]. Retrieved 24 January 2008 from http://info.gov.za/otherdocs/2007/ developmentindicator/index.html.

RITTER, J. (2006). Flach Spielen, hoch Gewinnen. Frankfurter Allgemeine Zeitung, 5 July 2006, p. 20.

SANTO, C. (2005). The Economic Impact of Sports Stadiums: Recasting the Analysis in Context. Journal of Urban Affairs, 27(2), 177- 192.

SAPA (2006). Opposition Parties Question Durban Stadium Plan. Witness. Durban, 14 July 2006, p. 2.

SCHAUG, E. (2006, 25 July 2006). No Easy Decision on 2010 Stadium. Cape Times, p. 2.

SEALE, L. (2007, 17 January 2006). Fort Ellis Leading the Way. Star, p. 5.

STURGESS, B., \& BRADY, C. (2006). Hosting the Fifa World Cup - Economic Boom or Winner's Curse? World Economics, 7(4), 145-164.

SZYMANSKI, S. (2002). The Economic Impact of the World Cup. World Economics, 3(1), 169-177.

TEIGLAND, J. (1999). Mega-Events and Impacts on Tourism: The Predictions and Realities of the Lillehammer Olympics. Impact Assessment and Project Appraisal, 17(4), 305-317.

TU, C. C. (2005). How Does a New Sports Stadium Affect Housing Values? The Case of Fedex Field. Land Economics, 81(3), 379-395.

UNTERREINER, F. P. (2006). Fußball-WM und Olympia: Profit und Prestige für den Gastgeber. Frankfurter Allgemeine Zeitung, March 10, 2006, pp. 10-11.

VAN DER WESTHUIZEN, T. (2007, 9 March 2007). Begroting Vir Groenpunt - Stadium Goedgekeur. Die Burger, p. 2.

WEBB, B. (2007, 8 March 2007). Bidding War Kicks Off. Cape Times, p. 1. 
YELD, J. (2006). City Short of R3.8bn for 2010. Cape Argus, Cape Town, 20 July 2006, p. 1. 


\section{Hamburg Contemporary Economic Discussions}

(Download: http://www.uni-hamburg.de/economicpolicy/discussions.html)

01/2005 FEDDERSEN, A. / MAENNIG, W.: Trends in Competitive Balance: Is there Evidence for Growing Imbalance in Professional Sport Leagues?, January 2005.

02/2005 SIEVERS, T.: Information-driven Clustering - An Alternative to the Knowledge Spillover Story, February 2005.

03/2005 SIEVERS, T.: A Vector-based Approach to Modeling Knowledge in Economics, February 2005.

04/2005 BUETTNER, N. / MAENNIG, W. / MENSSEN, M.: Zur Ableitung einfacher Multiplikatoren für die Planung von Infrastrukturkosten anhand der Aufwendungen für Sportstätten - eine Untersuchung anhand der Fußball-WM 2006, May 2005.

01/2006 FEDDERSEN, A.: Economic Consequences of the UEFA Champions League for National Championships - The Case of Germany, May 2006.

02/2006 FEDDERSEN, A.: Measuring Between-season Competitive Balance with Markov Chains, July 2006.

03/2006 FEDDERSEN, A. / VÖPEL, H.: Staatliche Hilfen für Profifußballclubs in finanziellen Notlagen? - Die Kommunen im Konflikt zwischen Imageeffekten und Moral-Hazard-Problemen, September 2006.

04/2006 MAENNIG, W. / SCHWARTHOFF, F.: Stadium Architecture and Regional Economic Development: International Experience and the Plans of Durban, October 2006. 


\section{Hamburg Contemporary Economic Discussions}

(Download: http://www.uni-hamburg.de/economicpolicy/discussions.html)

01

02

03

04

05

06

07

08

O9

10

11

12

13

AHLFELDT, G. / MAENNIG, W.: The Role of Architecture on Urban Revitalization: The Case of "Olympic Arenas" in Berlin-Prenzlauer Berg, 2007.

FEDDERSEN, A. / MAENNIG, W. / ZIMMERMANN, P.: How to Win the Olympic Games - The Empirics of Key Success Factors of Olympic Bids, 2007.

AHLFELDT, G. / MAENNIG, W.: The Impact of Sports Arenas on Land Values: Evidence from Berlin, 2007.

DU PLESSIS, S. / MAENNIG, W.: World Cup 2010: South African Economic Perspectives and Policy Challenges Informed by the Experience of Germany 2006, 2007.

HEYNE, M. / MAENNIG, W. / SUESSMUTH, B.: Mega-sporting Events as Experience Goods, 2007.

DUST, L. I MAENNIG, W.: Shrinking and Growing Metropolitan Areas - Asymmetric Real Estate Price Reactions? The Case of German Single-family Houses, 2007.

JASMAND, S. / MAENNIG, W.: Regional Income and Employment Effects of the 1972 Munich Olympic Summer Games, 2007.

HAGN, F. / MAENNIG W.: Labour Market Effects of the 2006 Soccer World Cup in Germany, 2007.

HAGN, F. / MAENNIG, W.: Employment Effects of the World Cup 1974 in Germany.

MAENNIG, W.: One Year Later: A Re-appraisal of the Economics of the 2006 Soccer World Cup, 2007.

AHLFELDT, G., MAENNIG, W.: Assessing External Effects of City Airports: Land Values in Berlin, 2007.

AHLFELDT, G.: If Alonso was Right: Accessibility as Determinant for Attractiveness of Urban Location, 2007.

AHLFELDT, G.: A New Central Station for a Unified City: Predicting Impact on Property Prices for Urban Railway Network Extension, 2007. 


\section{Hamburg Contemporary Economic Discussions}

(Download: http://www.uni-hamburg.de/economicpolicy/discussions.html)

FEDDERSEN, A. / MAENNIG, W.: Arenas vs. Multifunctional Stadia Which Do Spectators Prefer?, 2007.

AHLFELDT, G. / FEDDERSEN, A.: Geography of a Sports Metropolis, 2007.

FEDDERSEN, A. / GRÖTZINGER, A. / MAENNIG, W.: New Stadia and Regional Economic Development - Evidence from FIFA World Cup 2006 Stadia, 2007.

AHLFELDT, G. / MAENNIG, W.: Monumental Protection: Internal and External Price Effects, 2008.

MAENNIG, W. / PORSCHE, M.: Managing the Feelgood at Mega Sport Events - Contributions to an Eclectic Theory Informed by the Experience of the FIFA World Cup 2006, 2008.

AHLFELDT, G.: The Train has Left the Station: Real Estate Price Effects of Mainline Realignment in Berlin, 2008.

MAENNIG, W. / WELLBROCK, C.-M.: Sozio-ökonomische Schätzungen Olympischer Medaillengewinne: Analyse-, Prognose- und Benchmarkmöglichkeiten, 2008.

MAENNIG, W. / ALLERMS, S.: South Africa 2010: Economic Scope and Limits, 2008. 

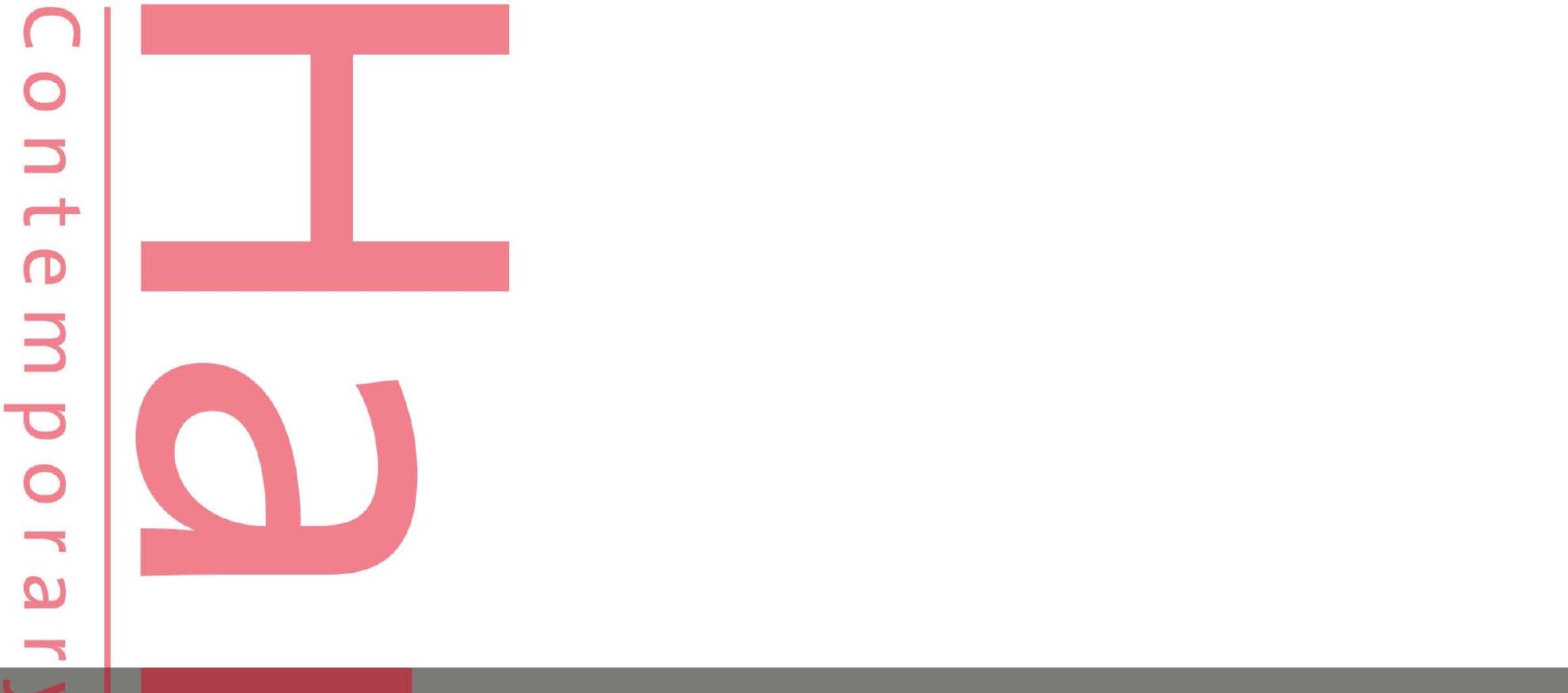

ISSN 1865-2441 (PRINT) ISSN 1865-7133 (ONLINE)

ISBN 978-3-940369-56-7 (PRINT) ISBN 978-3-940369-57-4 (ONLINE) 